\title{
WOLFENBÜTTEL, A MINOR GERMAN DUCHY BUT A MAJOR CENTER OF CRYPTOLOGY IN THE EARLY MODERN PERIOD
}

\author{
Gerhard F. Strasser \\ Presented in the Third European Historical Ciphers Colloquium, \\ May 18-19, 2017, Castle Smolenice in Slovakia
}

\begin{abstract}
This paper highlights cryptographic activities from 1540 to about 1680 at the small duchy-Brunswick-Lüneburg in northern Germany, not too far from Hanover (see Fig. 1 p. 2). The analysis shall proceed chronologically and present some relevant examples from the 16th century before focusing on the most important German cryptological author of his time, Duke August the Younger (1579-1666).
\end{abstract}

\section{Prefatory remarks}

The following analysis shall proceed chronologically and present some relevant examples from the 16th century before focusing on the most important German cryptological author of his time, August the Younger (1579-1666). His 1624 book of 493 pages (see [1]), Cryptomenytices et Cryptographiae Libri IX, and (Fig. 2, p. 3), ${ }^{1}$ became the cryptological standard work of the 17 th century and will be the focus of this paper. Some interesting cryptograms of his successors and a totally surprising, new authorship of the duke's handbook around 1900 will round out this analysis.

(C) 2017 Mathematical Institute, Slovak Academy of Sciences.

2010 Mathematics Subject Classification: 01A45, 94A60.

Keywords: cryptology, Duke August the Younger of Brunswick-Wolfenbüttel, Francis Bacon, Shakespeare.

${ }^{1}$ Lüneburg: Gebrüder Stern 1624. Duke August published the folio-size book under the pseudonym of "Gustavus Selenus"- "Gustavus" is easily recognized as an anagram of "Augustus" while "Selenus" refers to the lunar goddess Selene and plays upon the name "Luneburg" or "Lunaeburg", the "lunar" or "moon castle" where the work was printed. See Strasser [2]: Duke August the Younger of Brunswick-Luneburg (Gustavus Selenus) and His Cryptological Activities. In: Cryptologia 7 (1983), 193-217. 


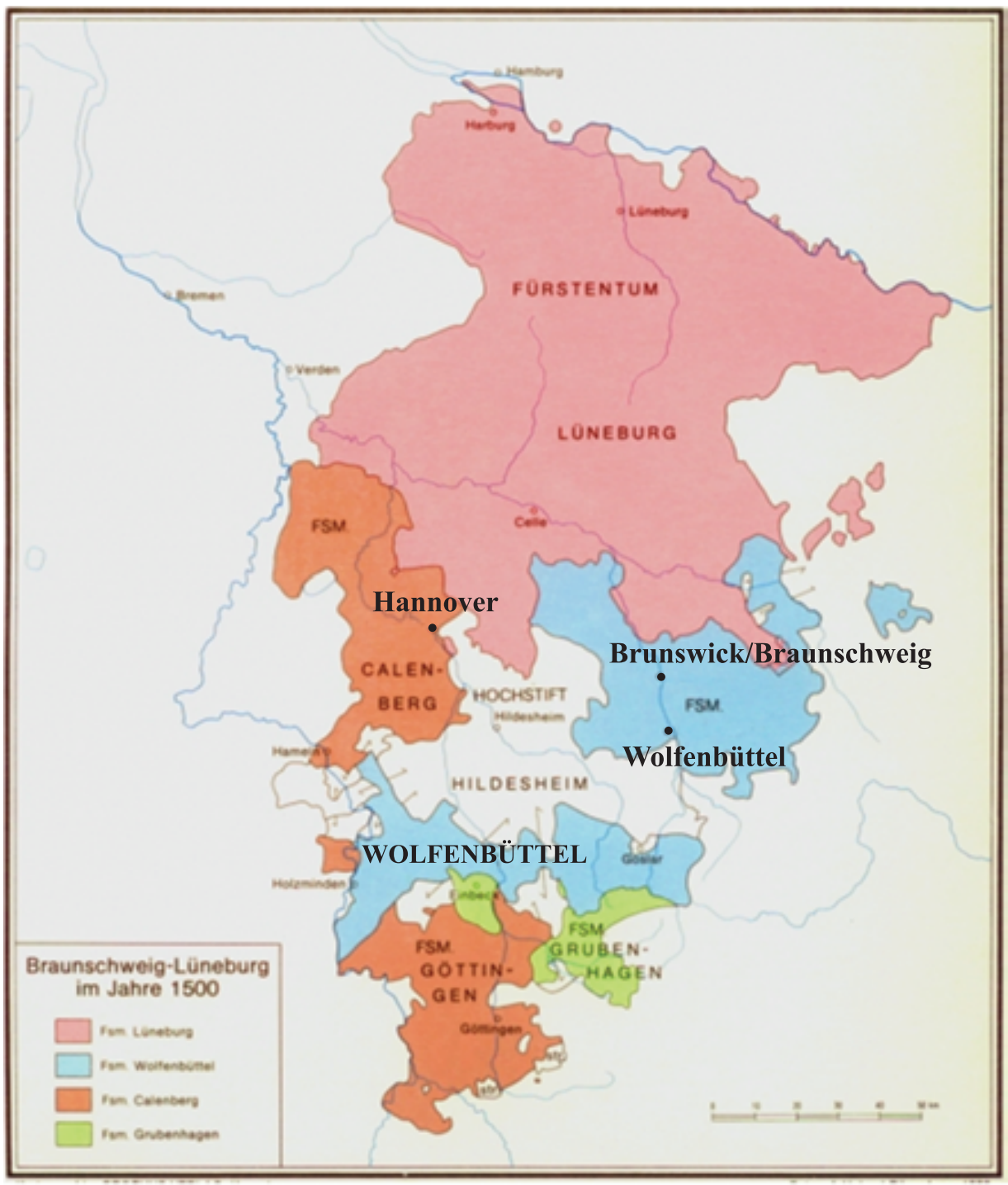

Figure 1. Overview of the Entire Guelph Duchy of Brunswick-Lüneburg around 1500 .

White areas belonging to the [Catholic] Bishopric of Hildesheim.

Major cities: Hannover, Brunswick/Braunschweig, Wolfenbüttel.

Blue areas: Duchy of Brunswick-Wolfenbüttel (part of the larger duchy). 


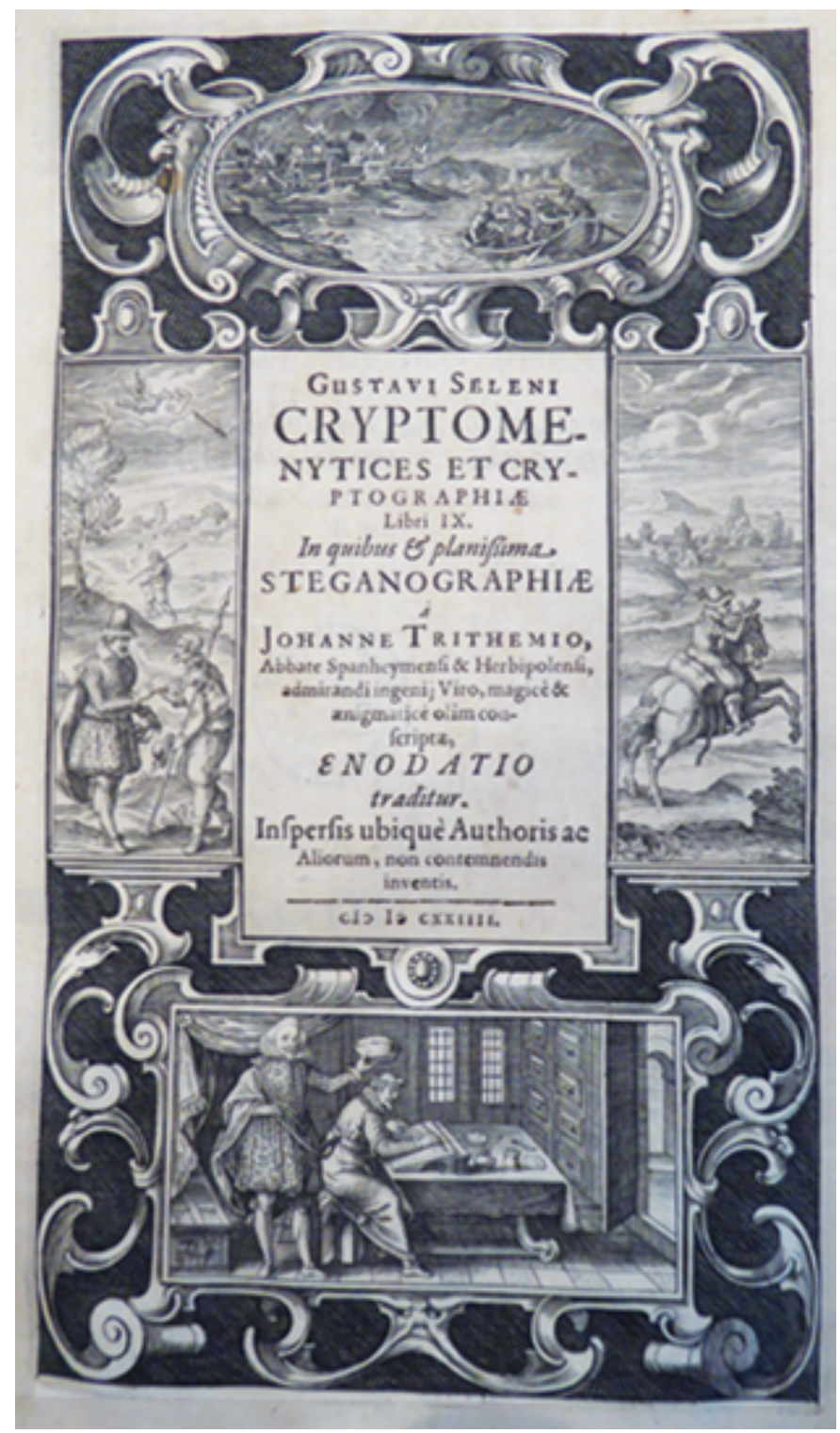

Figure 2. Title Page of Duke August the Younger's (pseudonym: Gustavus Selenus) Cryptological Compendium, Cryptomenytices et Cryptographiae Libri IX (Lüneburg: Stern 1624). Courtesy of Herzog August Bibliothek, Wolfenbüttel, for this illustration and numbers 5, 6, 7, 11, 13, $15,19,21,26,27$. 


\section{Early cryptological materials from the Wolfenbüttel court}

Both the archives of the Duke August Library, now one of the important European research centers in the Early Modern Period, and the State Archives at Wolfenbüttel keep fascinating cryptological materials that illustrate the problematic early years of the Protestant Reformation in northern Germany. ${ }^{2}$ A few very interesting pieces date from around 1540, a period when Duke Henry the Younger (1489-1568) had refused to introduce "the new religion" in his duchy. In 1542 he was expelled from his lands by troops from the Schmalkaldic League and kept in confinement; he returned 5 years later, still a staunch Catholic. ${ }^{3}$ The first of two relevant examples (certainly not written by the Duke himself but his secretary as there were no cipher secretaries yet at such small courts) is the Duke's rather intricate substitution cipher where various symbols replace the letters of the alphabet and some frequently used proper names but are also used for dual consonants and even include nulls ("Errantes") (Fig. 3, p. 5) ${ }^{4}$ The second piece is a letter written at the same time to Johann von der Asseburg, a member of the local Brunswick nobility and in imperial services. Here the Duke discusses aspects of his quarrel with the League and the Protestant estates; the page includes a long enciphered section with instructions to von Asseburg (Fig. 12, p. 21). ${ }^{5}$

\section{Duke August the Younger, scholar in his early years and ruler late in life}

While the death of Duke Henry in 1568 did not yet introduce Protestantism in his lands his successors ultimately espoused the new religion. Due to matters related to succession within the various branches of the dynasty of the Guelphs (Welfen) over the next fifty years August the Younger, born in 1579 as the seventh and the youngest child of Duke Henry of Dannenberg, a small lateral branch, had no hopes of ever gaining any influential position. Thus his parents gave him a more extensive education than was customary for young noblemen. ${ }^{6}$

\footnotetext{
${ }^{2}$ For the following see [3] Strasser: Geheime Schriften im Staatsarchiv: Kryptografie oder die Kunst, Geheimes zu verbergen und zu entschlüsseln. In: Braunschweigisches Jahrbuch für Landesgeschichte Vol. 91 (2010), pp. 85-109, here pp. 102-104.

${ }^{3}$ See 4] Wikipedia, https://de.wikipedia.org/wiki/Heinrich_II._(Braunschweig-Wolfenb\%C3\%BCttel) (accessed 03/23/2017).

${ }^{4}$ Niedersächsisches Staatsarchiv Wolfenbüttel (NLA-STA WF, 1 Alt 8) 5 .

${ }^{5}$ NLA-STA WF, 1 Alt 8, Nr. 490, BL. 36 r ${ }^{\circ} 6$.

${ }^{6}$ See Strasser [7] (Duke August, f. n. 1), pp. 197-201.
} 


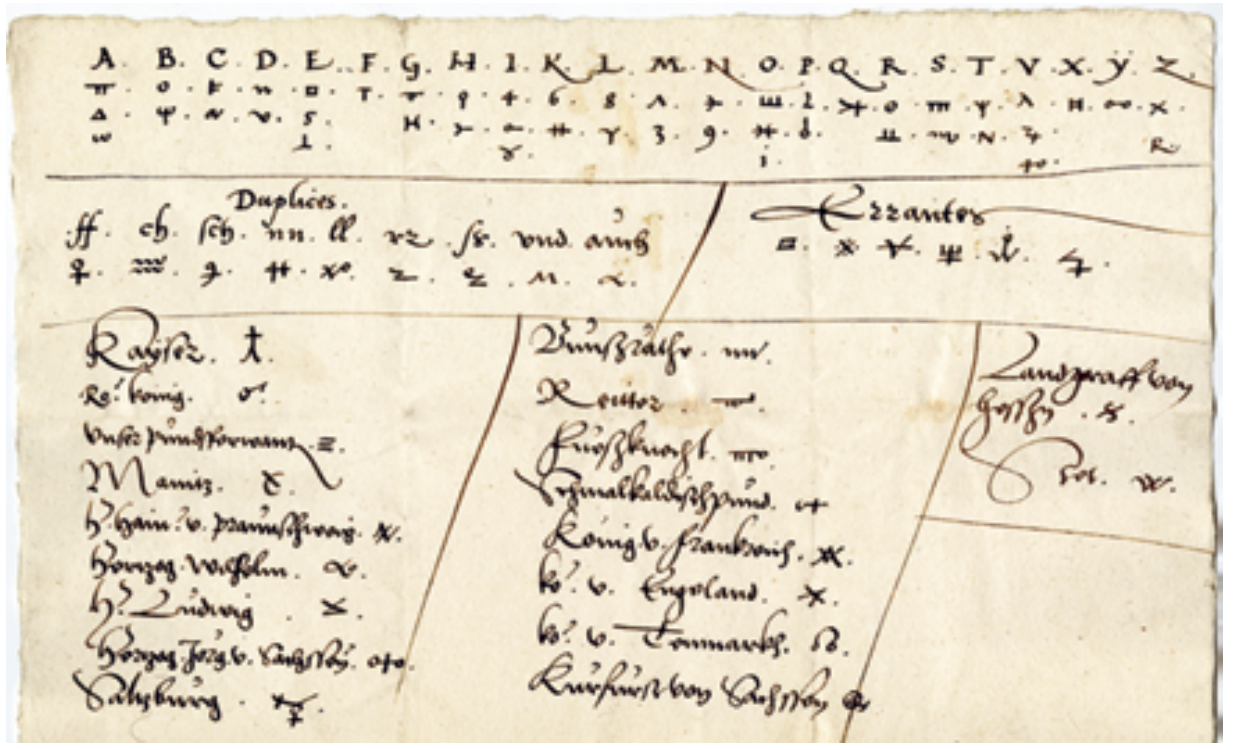

Figure 3. Treasures from the Wolfenbüttel State Archives: Cipher of (Catholic) Duke Henry the Younger during his Feud with the (Protestant) Schmalkaldic League (ca. 1540): Single-Letter Encipherment with various Symbols (also for double consonants and frequently used words/names) as well as Nulls ("Errantes"). Courtesy of Niedersächsisches Staatsarchiv Wolfenbüttel for this illustration and numbers 8, 9, 10, 12, 20.

His earliest book acquisition bears witness to his future interest in the speculative aspects of the natural sciences - three years after its reprint he purchased a copy of Giovanni Battista della Porta's Magia natvralis (see Fig. 13, p. 222). ${ }^{7}$ His marginal Nota bene in a work filled with interesting and sometimes incredible scientific oddities and curiosa occurs in the chapter that carried quite a few of the young duke's annotations and interested him the most (and to which he also referred in his Crytomenytices) ${ }^{8}$ [9, namely "De Ziferis". His mark highlights della Porta's suggestion to convey secret messages over distances by using large speaking tubes and is one of the earliest indications of the young man's fascination with cryptology.

After four years of study and a two-year grand tour where he visited, among other things, the major European libraries of his day, the young prince without lands finally took up residence in a small castle in the tiny city and county of Hitzacker by the Elbe river (see the map on Fig. 14, p. 23). It was there that within his very limited budget he gave free rein to collecting books across all

\footnotetext{
${ }^{7}$ Frankfurt/Main: Claude de Marne and Johann Aubry 1591. Nota Bene on p. 568 [8].

${ }^{8}$ Cryptomenytices (see [14, f. n. 1), fol. b1 $\mathrm{r}^{\circ}-\mathrm{b} 2 \mathrm{v}^{\circ}$.
} 
disciplines and in 1616 published his first work, an adaptation of a Spanish chess manual. ${ }^{9}$

By 1620 Duke August had acquired almost 200 volumes relating directly or indirectly to cryptology. At that point he decided to publish what in many ways can be considered a compendium of the relevant literature although the ongoing controversy over the works of the Benedictine abbot Johannes Trithemius (1462-1516) may have triggered off the duke's publication plans. ${ }^{10}$ Trithemius's incomplete cryptological Steganographia ${ }^{11}$ had remained in manuscript from 1500 to 1606 before it was finally printed - yet only to be put on the Catholic Index of Forbidden Books three years later for being suspect of black magic. The abbot's second cryptological work, Polygraphia (see Fig. 15] p. 24), was more accessible and published two years after the abbot's death. By 1622, to resolve the allegation of black magic, the duke had acquired manuscripts of both works before trying to propose a solution to at least the first two of the three books of Steganographia. Thus the full title of Duke August's 1624 Cryptomenytices-a work divided into nine books-includes the reference to his attempts at elucidating the controversial cryptological publications of Trithemius.

\section{Duke August's Cryptological Compendium - - Crytomenytices - of 1624}

For the purposes of this analysis we shall gloss over the extensive section devoted to the justification of Trithemius in the duke's Book III, where he explicated the first two parts of Steganogaphia but threw in the towel when it came to its incomplete third book. He readily admitted that he could not understand its conjurations and astrological references, cited its incomplete state and suggested that at best it would belong to the field of "synthematology" or telepathy. Assuming that his readers could not decipher the material, either, but wanting to give access to it since he possessed one of the few known manuscripts he

\footnotetext{
${ }^{9}$ Das Schach-oder König-Spiel [...]. Leipzig: Henning Groß d. J. 1616 [10].

${ }^{10}$ For a detailed discussion of the various attempts at clearing Trithemius from the odium of black magic see, in particular, [11] Klaus Arnold: Johannes Trithemius (1462-1516). Quellen und Forschungen zur Geschichte des Bistums Würzburg 23. 2nd ed. Wiesbaden: Schöningh 1991, Ch. 10, "Der Magier", [12] G. F. Strasser: Lingua universalis: Kryptologie und Theorie der Universalsprachen im 16. und 17. Jahrhundert. Wolfenbütteler Forschungen 38. Wiesbaden: Harrassowitz 1988, especially Ch. I A.

${ }^{11}$ Steganographia: Hoc est: Ars per Occultam Scripturam Animi sui Voluntatem Absentibus aperiendi certa. The full subtitle reads: In quibus \& planißima STEGANOGRAPHIAE à JOHANNE TRITHEMIO, Polygraphiae libri sex [...]. [Basel]: Haselberg, 1518 [13.
} 


\section{WOLFENBÜTTEL, CENTER OF CRYPTOLOGY IN THE EARLY MODERN PERIOD}

decided to reprint the extant section of this third book in his Cryptomenytices, fully hoping that some later scholar would interpret it - which took all of 500 years. $^{12}$

When we now have a look at the 187 names in the prefatory index we will see right away that Duke August included classical authors who were of historical interest but whose cryptological import is marginal. The listing includes Augustinus, Dio Cassius, Plato just as much as hitherto almost unknown important figures in the field of cryptology like Jacopo de Silvestri or Dominicus van Hottinga, who in 1620 plagiarized Gabriel de Collange's French translation of the Polygraphia. By virtue of its all-inclusiveness Duke August's index ${ }^{13}$ identifies him as an honest compiler whose primary aim was to present to his readers a comprehensive overview of the material available in a given discipline. The nine books of Cryptomenytices have justly been considered the most important 17thcentury compendium in the field of secret communication, and the work was used for such research purposes. ${ }^{14}$ However, the very nature of this overview accounts for its relative obscurity among modern cryptologists: Contrary to some of his better-known contemporaries or predecessors such as Trithemius, Vigenère, della Porta, Cardano, Schwenter, or later Athanasius Kircher, Duke August cannot be credited with a single important cryptological invention. His sole goal in writing the Cryptomenytices was to present "the state of the art", for — as he put it in his Preface - cryptology to him was indeed an art form. ${ }^{15}$ Nonetheless he was fully aware of the almost unlimited potential of such a cryptological compendium

\footnotetext{
${ }^{12}$ Cryptomenytices (see [14 f.n. 1), pp. 119-129. Two Americans finally solved the puzzle: Thomas Ernst: Schwarzweiße Magie. Der Schlüssel zum dritten Buch der Steganographia des Trithemius. In: Daphnis: Zeitschrift für Mittlere Deutsche Literatur 25 (1996), pp. 1-205 and The Numerical-Astrological Ciphers in the Third Book of Trithemius's Steganographia. In: Cryptologia 22 (1998), pp. 318-341, as well as Jim Reeds: Solved: The Ciphers in Book III of Trithemius's Steganographia. In: Cryptologia 22 (1998), pp. 291-317. — In an unrelated ScienceBlogs-entry (http://scienceblogs.de/klausis-krypto-kolumne/2016/12/06/ a-musical-cryptogram-from-the-17th-century/, accessed 06/08/2017) Thomas Ernst casually mentions on Dec. 12, 2016, that the Steganographia manuscript, where Duke August inserted numerous corrections in the first two books but could not understand the third, incomplete one - was actually not the expected autograph copy for which he must have dearly paid.

${ }^{13}$ In his own copy of the 1624 publication (Herzog August Bibliothek, Fb $4^{\circ}$ 81) the duke added one more name, that of the diplomat, humanist, and botanist Augerius Busbegus/Busbequius (Ogier Ghislain de Busbecq or Busbeck), 1522-1592.

${ }^{14}$ David Kahn more or less glosses over the importance of the Duke's work in his brief mention: The Codebreakers. The Story of Secret Writing. Reprint, rev. and updated. New York: Simon \& Schuster 1996, 154 [15].

${ }^{15}$ Cryptomenytices (see [14], f. n. 1), fol. a6 vo: Sed tantùm circa genera, secundum Authoris consilium \& filum occupati fuimus, non ut studiosi Artis hujus, ibi consisterent, sed hisce benè perspectis \& cognitis, progrederentur [...] - so that those who are studying this Art would not leave it at that but continue to inform themselves further after having thoroughly digested and understood it. (My underlining).
} 


\section{GERHARD F. STRASSER}

at a time when the Thirty Years' War (1618-1648) had already ravaged parts of the German lands although he explicitly hoped that his Cryptomenytices would not be put to such use. ${ }^{16}$ This very application was bound to happen, of course: We have a rare documentation of such cryptological use in a letter written in 1655 by Étienne Polier, a Swiss informant residing in Paris. Polier offered Samuel Hartli(e)b, a German scholar in London closely associated with Oliver Cromwell's government, to communicate privileged information "even from the Cabinet".

Ie [je] say quelque fois d'assez bonnes nouuelles, mesmes du Cabinet, si vous agreez que ie vous die ce [qu'il corrected: que] ie sauray de plus secret en chifres, I'y suis assez accoustumé $\mathscr{G}$ en say peut estre des plus beaux, cest pourquoy ie suiuray facilement vos ordres, soit qu'il vous plaise de m'en donner quelqu'un des vostres a suivre; ou que vous en desiriez vn des miens, ou que vous mind m'en indiquiez quelqu'un de ceux qui vous agrée le plus dans Selenus qui en a traitté en Maistre.

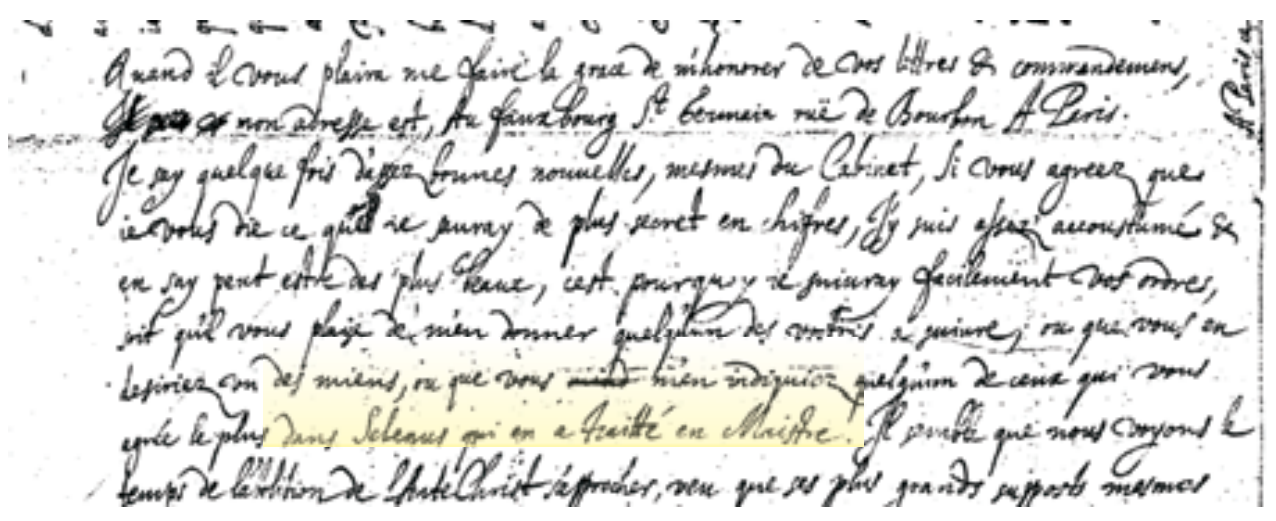

Figure 4. An Example of the Rare Use of Cryptomenytices for Secret Communication: Letter from Étienne Polier to "Monsieur Samuel Hartlieb Esquier" in London, dated Paris, 8 October 1655. (My underlining)

Such letters would have to be encrypted, and Polier suggested to adopt one of Hartlib's ciphers or one of his own, "or that you indicate to me one of those which you prefer most in Selenus [Duke August's pseudonym], who has treated them in a masterful way" (see Fig. 4. p. 8) ${ }^{17}$ Needless to say that Polier, who must

\footnotetext{
${ }^{16}$ Ibid., fols. a3 $\mathrm{v}^{\circ}$-a $4 \mathrm{r}^{\circ}$.

${ }^{17}$ Letter written by Étienne Polier to Monsieur Samuel Hartlieb Esquier dated Paris, October 08, 1655. Sheffield University Libraries, Hartlib MSS 7/118/1-2. See [16] Strasser: "The
} 


\section{WOLFENBÜTTEL, CENTER OF CRYPTOLOGY IN THE EARLY MODERN PERIOD}

have had access to Cryptomenytices in Paris, assumed that Hartlib also owned or could consult the duke's handbook in London.

Despite the vast collection of secondary sources at his disposal there are certain areas that Duke August simply could not know, in particular the important body of cryptological works from Arab countries whose originals are just now being discovered and edited. It is a moot point to speculate how much of Al-indi's work might have been accessible to western innovators like Alberti in his 1467 Trattato di Leon Battista Alberti sulla Cifra, ${ }^{18}$ which was not printed until a century later. And even this first obscure printing in the midst of unrelated works in no way disseminated information on Alberti's groundbreaking invention that made him the "Father or Western Cryptology", to quote David Kahn's assessment. ${ }^{19}$ This relative obscurity is certainly the reason why Duke August is not aware of Alberti's accomplishments and only knows the cipher disk through 18] Gabriel Collange's 1561 translation of the Polygraphia into French ${ }^{20}$ from where he selected one of the more than a dozen relevant illustrations, copied and expanded it and had a simplified version printed (Fig. 16, p. 25). And while the lack of direct information on Alberti's invention is quite understandable it is somewhat surprising that Duke August had not acquired the earliest cryptological book in German until years after the publication of his Cryptomenytices: Samuel Zimmermann's Etliche fürtreffentliche Gehaimnussen [...] [19] (see Fig. 22, p. 31) ${ }^{21}$ of 1579 was indeed difficult to identify as a work on secret communication as it was included as the second part of a book dedicated to letterwriting, New Titularbüech [...]. Zimmermann's selective presentation certainly made use of della Porta's Magia natvralis, Vigenère's Traicté des Chiffres or Book VI of the Polygraphia of Trithemius, among other sources, but would have contained little information that the duke had not touched upon.

These two publications are indeed rare omissions among the more than 100 authors that may have constituted the corpus of cryptological information in the

Rise of Cryptology in the European Renaissance". In: Karl de Leeuw and Jan Bergstra, eds. The History of Information Security: A Comprehensive Handbook. Amsterdam et al.: Elsevier 2007, pp. 277-325, here p. 298.

${ }^{18}$ The rare manuscript is kept at the Vatican Library, Ms. Vat. Chig. M II 49. The material was first published in 1568 in Alberti's Opuscoli morali [...]. Venice: Francesco Franceschi [17. ${ }^{19}$ Kahn (see f. n. 14), pp. 125-130.

20 [18] Gabriel Collange: Polygraphie et Vniverselle escriture Cabalistique de M. I. Tritheme Abbé [...]. Paris: Kerver 1561. The illustrations appear in the appendix, where various cipher disks are shown beginning on fol. $252 \mathrm{r}^{\circ}$. Simplified reproduction in Cryptomenytices (see f.n. 1), p. 177.

${ }^{21}$ Published as the second part of New Titularbüech: Das ist, Wie man ainer Jeden Person [... ] zuschreiben soll [.. .]. Etliche fürtreffentliche Gehaimnussen [. . . ] follows on pp. 107-167 without separate pagination. Published by the author himself in Ingolstadt. See [20] Strasser: Samuel Zimmermann's Gehaimnussen: The earliest cryptological book in German. In: Cryptologia 40 (2016), pp. 240-260. 


\section{GERHARD F. STRASSER}

early 17th century. With the exception of the writers just mentioned Duke August covers standard works such as Vigenère's Traicté of 1586, which interests him also for its cabalistic materials, Cardano's or della Porta's publications, as we shall see, but in addition - and this may indeed be the lasting merit of the Cryptomenytices — such rarely known works as the 1526 Opvs Novvum of the Florentine Jacobus de Silvestris [21] (pp. 360-367) or the Scotographia of Abramo Colorni [22] (Fig. 23, p. 32). ${ }^{22}$ Only Trithemius's two books are more extensively treated than this 1593 publication, to which the duke devotes some 60 pages (pp. 185-245) - fully aware of the potential of this polyalphabetic method of "Obscure Writing", as the title translates. Nearly four centuries later Daniel Jütte's [23] 2011 publication on this "Jew of Mantua", as Colorni called himself, finally gave credit to this almost failsafe system. ${ }^{23}$

This vast body of material comes into play beginning with Duke August's Book IV, which follows the discussion of the Steganographia. His analysis of the second cryptological work of Trithemius, the Polygraphia, occurs after some prefatory remarks which include a reference to Roger Bacon's short Speculum Alchymiae (p. 137) that the duke possessed in a 1614 collection of various alchemical publications. ${ }^{24}$ Never a true friend of alchemy he was only interested in one cryptographic method he found exemplified in Bacon's piece, namely acrostics, the stringing along of the first or last letters of a text of several lines. This leads on to the duke's analysis of the Polygraphia (pp. 144-145) which he strongly defends from attacks both by Girolamo Cardano and, to a lesser degree, della Porta. Cardano in 25] De Rerum Varietate inveighed against the abbot for having "put forth his invention in allegorical disguise". ${ }^{25}$ Duke August quotes Trithemius from his own dedicatory preface to Emperor Ferdinand II, where the abbot clearly argued that "in the system of polygraphy there are [...] secrets involved in allegory that may not be plain to the intelligence of every person". ${ }^{26}$

\footnotetext{
22 Jacobus de Silvestri: Opvs novvm [. . . ] pro cipharis, lingua Latina, Graeca, Italica [. . . . Rome: [no publisher] 1526 [21; Abram Colorni: Scotographia overo scienza di scrivere oscuro, facilissima, et sicurißima, per qual si voglia lingua [...]: Prag: Schumann 1593 (Fig. 23 p. 32 22]).

${ }^{23}$ Daniel Jütte: Geheimnisse übermitteln. Das Zeitalter des Geheimnisses: Juden, Christen und die Ökonomie des Geheimen (1400-1600). Göttingen: Vandenhoeck \& Ruprecht 2011, 2nd ed. 2012, Geheimnisse übermitteln, pp. 258-268 (Fig. 23 p. 322).

${ }^{24}$ Duke August used Opuscula quaedam chemica [...] (Frankfurt: Bringer 1614), which contain Speculum Alchymiae (subtitled in its first English translation of 1597 as The True Glass of Alchemy), a work attributed in this collection and in the current catalogue of the Herzog August Bibliothek to Helias Monachus [Franciscanus] 24.

${ }^{25}$ Girolamo Cardano: De Rerum varietate libri XVII. Basel: Petri 1557, Book 12, Ch. 61.

${ }^{26}$ Cryptomenytices (see f. n. 1), fols. a3 $v^{\circ}$-a $4 r^{\circ}$. English translation of this work by Dr. John William Henry Walden, dated around 1900.

https://archive.org/stream/TheCryptomenytics

AndCryptographyOfGustavusSelenusInNineBooks/Cryptomenytics\{\#\}page/n2/mode/1up (accessed 06/07/2017) [26].
} 
The duke takes the abbot at face value, which is why he comes to his defense and - while agreeing with della Porta's De Occvltis Literarum Notis $[\ldots]^{27}$ on the avowed importance of writing and of the alphabet ${ }^{28}$ - considers even Porta's attitude toward Trithemius's "allegory" too strong. Both critics, Duke August feels, should have fully appreciated the German abbot's ingenuity and inventiveness; as a German prince he cannot but snipe at the two Italians with all their important cryptological developments who, he feels, should be glad that for once a German scholar has devised such an ingenious system (p. 145).

Nonetheless even Duke August himself considers the sheer volume of the (word) lists in both publications overwhelming. For this reason he reprints a slightly modified polygraphic version taken from della Porta's De Occvltis literarum notis 28, the plagiarized version of 1593 of the Italian's earlier and ground-breaking publication, De Fvrtivis Literarum Notis, vulgò De Ziferis Libri IIII [29], which had come out in Naples in 1563. The duke deems this version superior and safer to a similar one found in one of his favorite German sources [30, the Steganologia \& Steganographia aucta: Geheime / Magische Red vnnd Schreibkunst [...], ${ }^{29}$ which reached him in 1622 while he was drafting his compendium. Its Nuremberg author, Daniel Schwenter, proposed to write ready-made letters to informed partners that would contain secret messages. Porta, on the contrary, resorted to a system much closer to Trithemius's polygraphic method, which the duke modified and printed on more than a dozen pages (pp. 147-161) (Fig. 28, p. 37). And although Duke August did not invent any new methods he certainly expanded and improved on existing ones, as his preparation of more concise German word lists similar to Porta's would show (pp. 161-167) (Fig. 17, p. 267).

Even though the duke operated on a very limited budget at his Hitzacker residence (his wife had to meticulously document household expenses for the small court) he established a wide network of book agents and, through them, also engravers who prepared the intricate illustrations for his Cryptomenytices. In Book VI - devoted in particular to methods of transposition - he displayed a number of grilles, pigpens and similar ciphers and referred to a collection of various methods of concealment by Johann Walch. The ninth fable in

\footnotetext{
${ }^{27}$ Giovanni Battista della Porta: De Occvltis literarvm notis [...]. Montbéliard: Foillet 1593, Book II, Ch. 19. On this plagiarized version of the 1563 publication see 27. Strasser: Die europäische Rezeption der kryptologischen Werke Giovanni Battista Della Portas. In: MorgenGlantz. Zeitschrift der Christian Knorr von Rosenroth-Gesellschaft 18 (2008), pp. 85-112.

${ }^{28}$ Della Porta (see f.n. 27), Book II, Ch. 1.

${ }^{29}$ Janus Hercules de Sunde (pseudonym of Daniel Schwenter): Steganologia \& Steganographia aucta, Geheime/Magische Red vnnd Schreibkunst [...]. Nuremberg: Halbmayer [1622?], Book V 30.
} 


\section{GERHARD F. STRASSER}

Walch's 1609 work, Decas Fabularum Humani Generis [...] 31. ${ }^{30}$ — aptly titled "Simia" (apelike imitation) — treated the history of printing, secret inks and various methods of encipherment. Hardly any other title in the duke's collection contains such a plethora of materials that were even worked into engravings. One such illustration - a perfect steganographic example as long as the quality of the picture does not raise suspicion - represents a hunting scene where the eyes of all the animals and the hunters, taken together, encipher a message that Duke August deciphered and wrote above the illustration (Fig. 18, p. 27) ARS INIMICUM NON HABET, NISI IGNORANTEM (Art has no enemy except for ignoramuses). Always intent on displaying his own capabilities the duke had the Augsburg engraver Lucas Kilian — who also executed his intriguing title page — prepare another genre picture of superior quality (p. 341) (Fig. 19, p. 28). Not only the eyes of all men and animals on the ground and in the sky but even the apples and the stars count in this enciphered illustration that would certainly pass the scrutiny of any censor - but was, of course, by far too involved to be of any practical use. A "steganographic tree" dedicated to Duke August on his birthday (Fig. 20, p. 29) shows that the dedicatee had to add a branch with one more apple to properly complete the message hidden in the apples, where each apple above the alphabet line that was added by the duke under the tree roots and-when deciphered from the top down-yields a letter of the cryptogram:

\section{INDE HIC LONGA TIBI SINT TEMPORA PROSPERA FIAT}

(May prosperous times be granted you from now on for a long time). ${ }^{31}$

This same Book VI of the Cryptomenytices displays yet another of its author's special efforts: After some prefatory explanations in a section devoted to musical ciphers (pp. 321-324) he commissioned Friedrich Holland(t), a Lüneburg musician, to compose a short piece in four voices (Fig. 21, p. 30). The tenor notes embedded a cryptogram that had to be conceived after 1620, when the Spanish general Ambrosio Spinola began invading the Palatinate just as the duke was drafting his compendium: The message, "Der Spinola / ist in die Pfaltz gefallen: Væ illi", reflects a German Protestant's woeful concern over the loss of these

\footnotetext{
${ }^{30}$ Strasbourg: Zetzner 1609. In the endpapers Duke August - following an illustration on pages 220-221 - added a modified Vigenère tableau of 25x25 letters and symbols. He also heavily annotated Ch. 9, "Simia". Illustration after p. 201. See 32 Strasser: Die kryptographische Sammlung Herzog Augusts: Vom Quellenmaterial für seine "Cryptomenytices" zu einem Schwerpunkt in seiner Bibliothek. In: Wolfenbütteler Beiträge 5 (1982), pp. 90-91 and p. 106.

${ }^{31}$ Niedersächsisches Staatsarchiv Wolfenbüttel (1 Alt 22 Nr. 227, Bl. 47-48). See 33. Strasser (Geheime Schriften, f.n. 2) and 34] Klaus Schmeh: "Versteckte Nachrichten in Modezeichnungen, Grashalmen und Apfelbäumen". In: ScienceBlogs, May 21, 2015. http://scienceblogs.de/klausis-krypto-kolumne/2015/05/21/versteckte-nachrichten-in-modezeichnungen-grashalmen-und-apfelbaeumen/ (accessed 06/08/2017). (There is a minor linguistic error in the cryptogram, which should read "[...] longa tibi [...]".)
} 


\section{WOLFENBÜTTEL, CENTER OF CRYPTOLOGY IN THE EARLY MODERN PERIOD}

reformed lands to the forces of the Catholic emperor. Once more Duke August is aware of the pitfalls of poorly executed visual or musical encipherments: The short composition is so pleasant that no censor would have suspected an imbedded message in these notes; it was recorded by a string quartet and is available on YouTube. ${ }^{32}$

Let me close on this (musical) note, which could at least give you an idea of the breadth of material presented in the Cryptomenytices. The end of the Thirty Years' War heralded in a period of reconstruction; Duke August, who in 1635, at age 56 - somewhat unexpectedly — became reigning Duke of BrunswickLüneburg, soon was the senior prince in the German lands. Despite his penchant for burning witches at the stake he was a beloved ruler and expanded his library to reach more than 135.000 titles by the time he died in 1666. His interest in cryptology was rekindled after 1650 when he entered into a correspondence with the Jesuit Athanasius Kircher in Rome. A touching cryptographic exercise (Fig. 5. p. 14) inserted to this day in [37. August's copy of Kircher's 1663 publication of a Polygraphia nova et vniversalis ${ }^{33}$ bears witness to the 84 -year-old duke's enduring passion. Only his fourth son, Ferdinand Albrecht I (1636-1687), similarly well educated like his father but also without lands, showed a continued interest in cryptology, as detailed exercises penned into his own copy of the Polygraphia nova show (Fig. 6, p. 15). ${ }^{34}$ As if to document Ferdinand Albrecht's reverence for his father the title page of his own copy of the Cryptomenytices (Fig. 7. p. 16) shows his Nb: effigies Authoris (image of the author) above the head of a well-dressed, bearded gentleman (Duke August) holding a crown of honor over the head of another man at a writing desk, namely, Trithemius. While this identification of August on the title page of his compendium may not seem terribly revealing in view of the duke's extant instructions to his Augsburg

\footnotetext{
${ }^{32}$ Despite numerous efforts over the past 25 years there is no trace of a Friedrich Holland(t), musician in Lüneburg although Herzog August's close connections with this city, where the Stern Brothers published the Cryptomenytices, after all, do suggest that this composition was indeed commissioned there. For an extensive discussion of this problem see 35. Klaus Schmeh: A musical cryptogram from the 17th century. In: ScienceBlogs, Dec. 16, 2016. http://scienceblogs.de/klausis-krypto-kolumne/2016/12/06/a-musical-cryptogram-from-the-17th-century/ (accessed 06/08/2017).

The 90-second musical cipher is available on YouTube in two versions: https://youtu.be/XjHtiXE8Iys(06/12/2017) See also [36] Strasser: Musik(noten)chiffren oder die 'widernatürliche' Kunst, Musik zu geheimer Kommunikation zu verwenden. In: Hartmut Laufhütte, ed. Künste und Natur in Diskursen der Frühen Neuzeit. Wolfenbütteler Arbeiten zur Barockforschung 34-35. Wiesbaden: Harrassowitz 2000, Part II, pp. 1107-1121, here pp. 1108-1111.

${ }^{33}$ Polygraphia nova et vniversalis ex Combinatoria Arte detecta [...]. Rome: Varesius 1663.

${ }^{34}$ Herzog August Bibliothek, Fb $4^{\circ}$ 78, front matter [38. See also [39] Strasser: Geheimschrift. In: Sammler-Fürst-Gelehrter. Herzog August zu Braunschweig und Lüneburg: 1579-1666. Catalogue of the Herzog August Bibliothek 27. Wolfenbüttel: Herzog August Bibliothek 1979, pp. 181-191.
} 


\section{GERHARD F. STRASSER}

- H I L O B E R G

- A C D F K M N P

- Q S T U W X Y Z

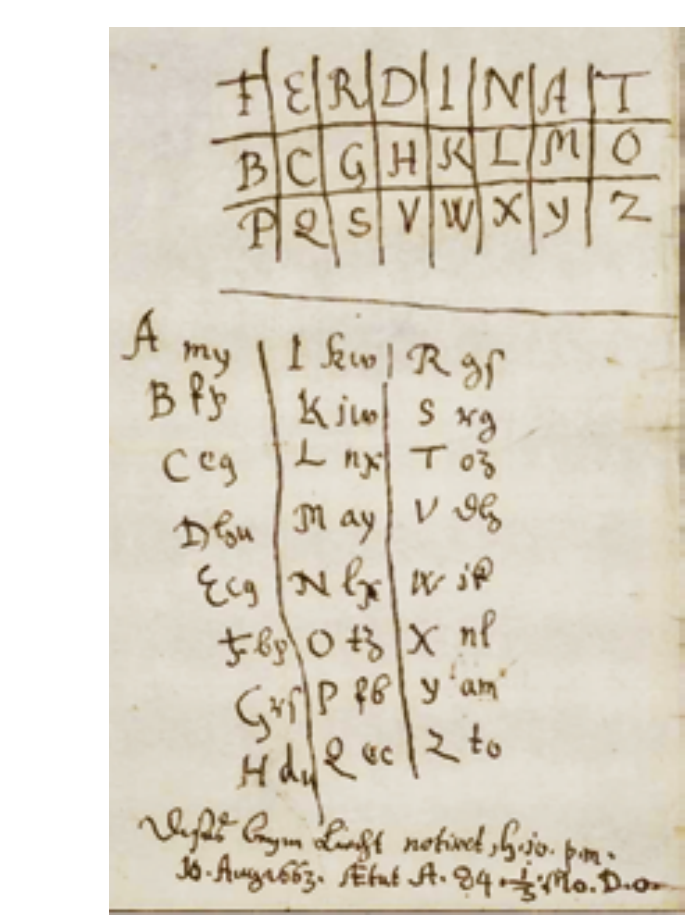

The Duke's own recorded date of this excercise:

"Dißes beym Liecht notiret, h. 10. p. m. 16. Aug. 1663.

AEtat. A. 84. 1/3; Mo. D. O." (I have jotted this down by candle light at 10 p.m. on 16 Aug. 1663, Age 84 and $1 / 3$ months.)

Figure 5. Cipher Excercise by Duke August Inserted in His Copy of Athanasius Kircher's 1663 Polygraphia nova. The Duke had already used this cipher in 1642 in communication with Hilmer von Oberg. Keyword here "Ferdinat" (you can see it on the first line of the figure).

engraver ${ }^{35}$ it would have contributed to leading ad absurdum a totally different interpretation of this illustrated page some 270 years later.

Apart from Ferdinand Albrecht I his brothers Rudolph August and Anton Ulrich, jointly governing the duchy after 1666, continued collecting the everdwindling cyrptological literature of the later 17th century. Two examples from their own diplomatic communication, documenting their use of cryptology and again executed by secretaries, can show a clear shift in cryptological methods toward an increased preference of detailed nomenclators (Fig. 8 , p. 17 and Fig. 9, p. 18).

${ }^{35}$ Herzog August Bibliothek, Cod. Guelf. 63.2 Extrav. 


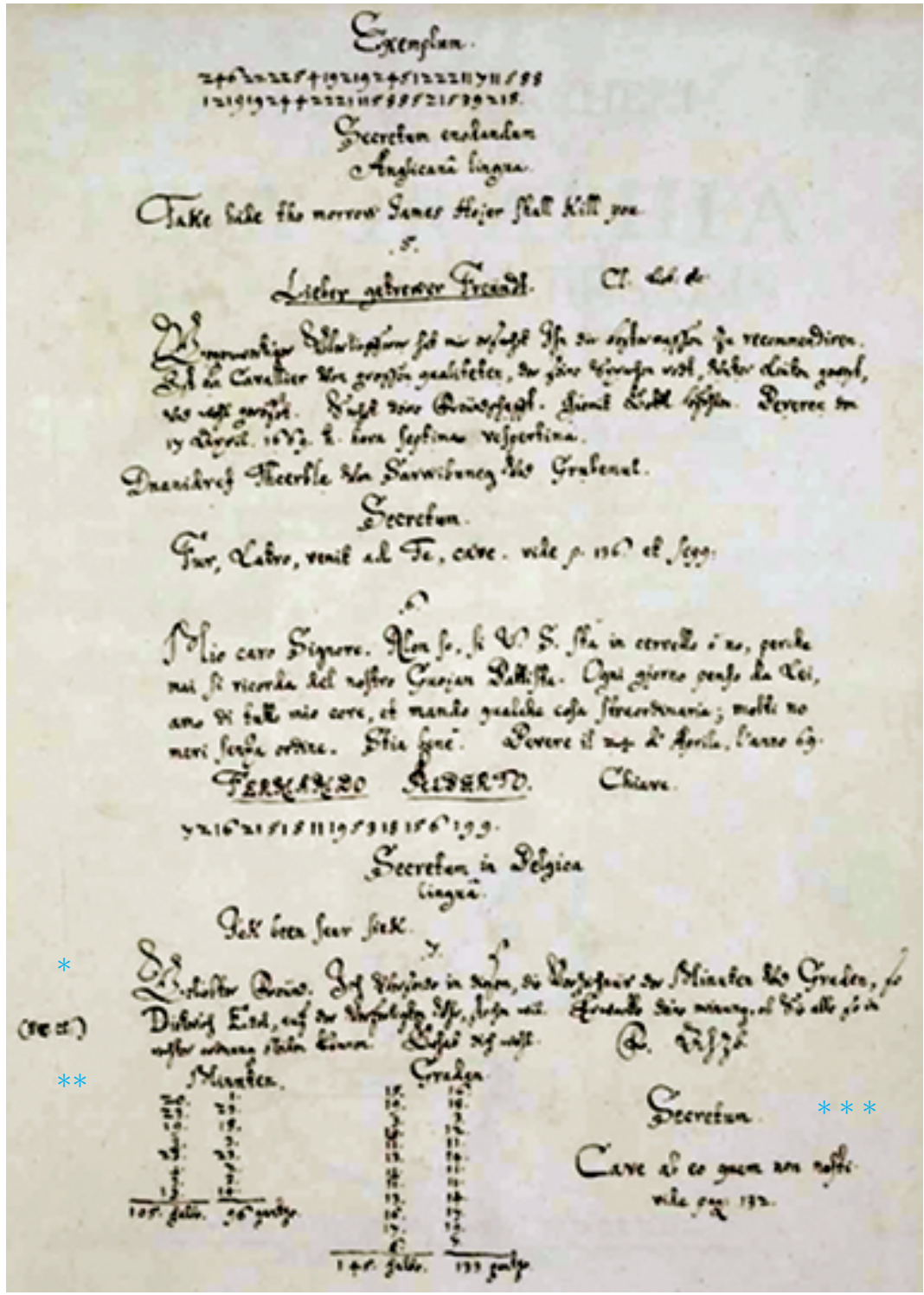

FiguRE 6. * Cover Letter of Ferdinand Albrecht: Geliebter Freünd. Jch Vbersende in diesem, die Verzeichnis der Minuten Vnd Graden, so Dieterich Edel, auf der Verfertigten Vhr, stechen wil. Erwarte deine Meinung, ob Sie alle so in rechter ordnung bleiben können. Gehab dich wohl. F. Ahzb. (The cover letter has the function to use the capital letters in the text to refer to the various rows of alphabets in Kircher's book that are necessary for decipherment.)

** Insertion of Ciphers with the help of Minutes and Degrees.

$* * *$ Cleartext Warning: CAVE AB EO QVEM NON NOSTI (Watch out for the one you do not know.) 
F. A. D. B. et Luneb.

(i.e., Ferdinand Albrecht, H.

(i.e., Herzog/Duke))

of B(runswick) and Lüneburg

\section{NB effigies authoris}

(in Duke August's handwriting [presumably when he gave the volume to his son, Ferdinand Albrecht, the only one of his four children interested in cryptology]. The NB is placed right over the head of a portrait of well-dressed, balding Duke August, represented with his characteristic pointed beard. In the lower illustration he is holding a kind of crown of honor over the head of Trithemius, who is shown writing at a desk [exactly as the instructions to Lucas Kilian requested]).

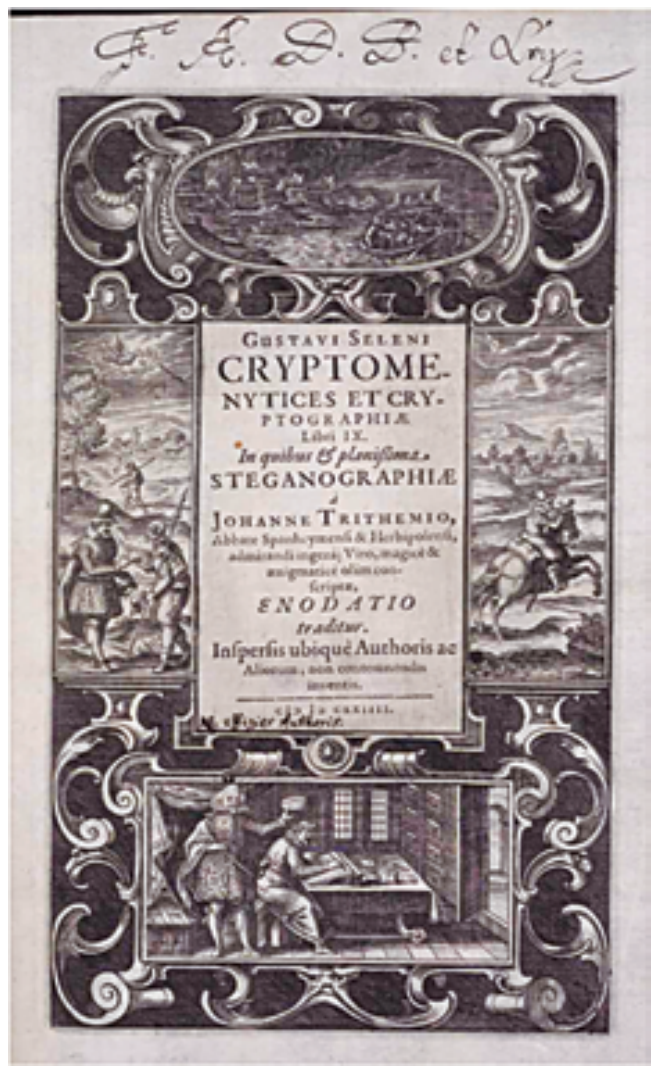

FIgURE 7. Duke August's Cryptomenytices et Cryptographi Libri IX (Lüneburg: Gebr. Stern 1624): Title page of the copy owned by his 4th Son, Duke Ferdinand Albrecht, with Reference to "NB effigies authoris" (image of the author).

\section{Francis Bacon \\ or a surprising new authorship of Cryptomenytices}

More than a century after a British author, Sir Edwin Durning-Lawrence, issued Bacon is Shake-Speare ${ }^{36}$ as a culmination of years of research into Sir Francis Bacon's authorship of Shakespeare's work, aficionados of this theory still consult copies of Cryptomenytices at the Herzog August Bibliothek. Their own

\footnotetext{
${ }^{36}$ London: Gay \& Hancock 1910. See [40, Ch. XI] On page 136 of the Shakespeare Folio of 1623, being a portion of the play Love's Labour's Lost, and its connection with Gustavi Seleni 'Cryptomenytices', pp. 103-133, especially pp. 112-113. Cf. 41] Strasser: Herzog Augusts Handbuch der Kryptographie: Apologie des Trithemius und wissenschaftliches Sammelwerk. In: Wolfenbütteler Beiträge 8 (1988), pp. 99-120, here pp. 119-120.
} 


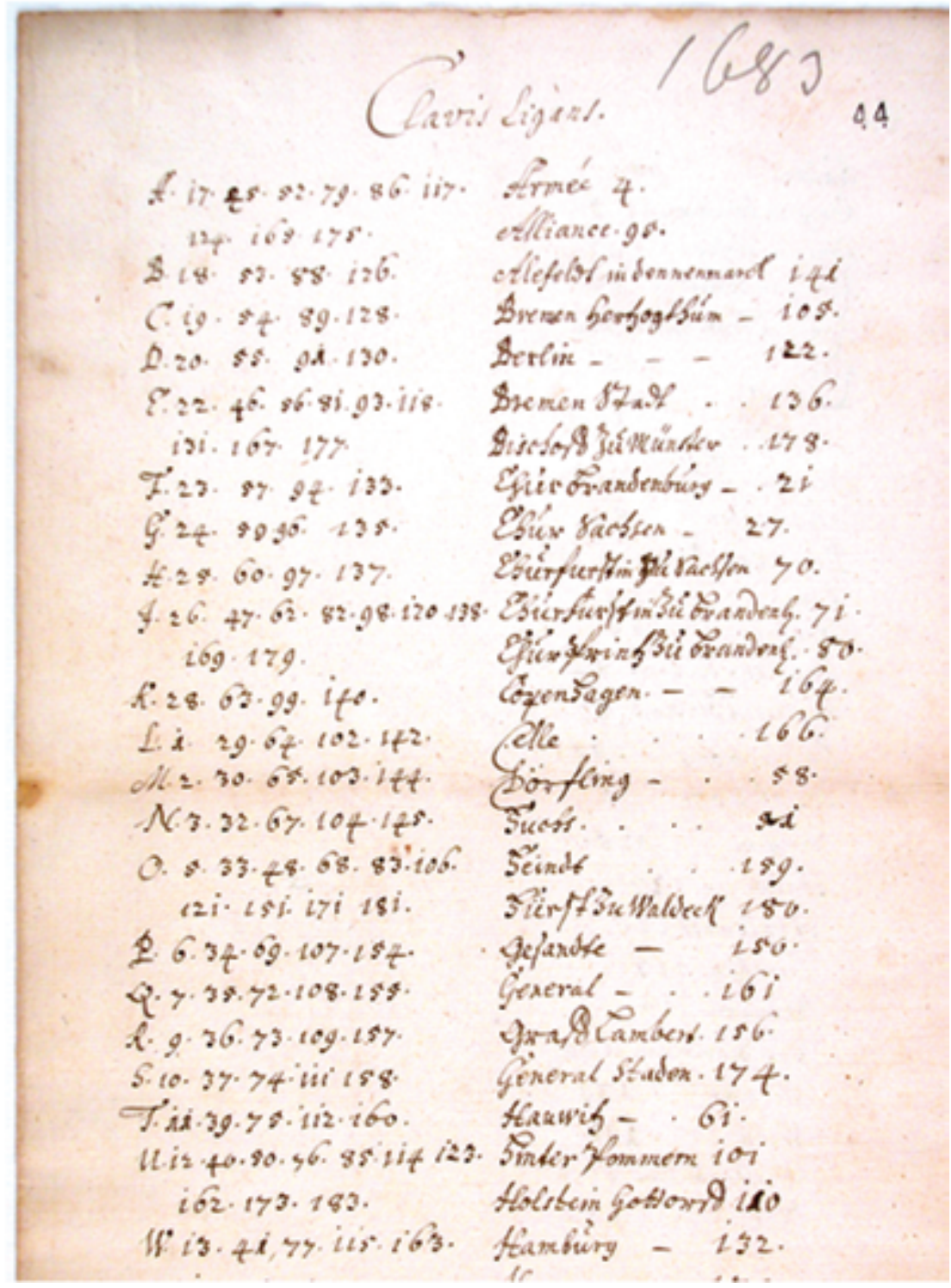

\section{Left Column:}

Single letters of the alphabet assigned to one- to three-digit numbers:

For "A"- $17,45,52,79$, etc.

For "B"- 18, 53, 88, 126.

Right Column:

For frequently used words or names:

Figure 8. One of two parts of the Nomenclator from the time of the reigning two sons of Duke August, dated 1683 and issued to their Chancellor, "Präsident von Heimburg": Clavis ligans for enciphering (the orignal page 44). 
Cavis solvens.

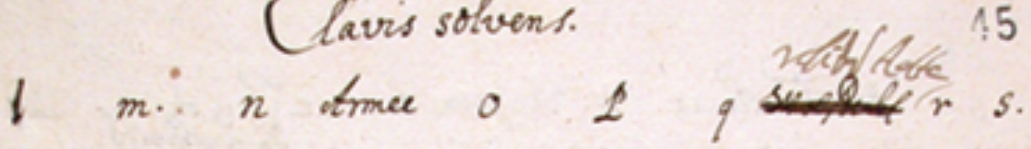

$\begin{array}{lllllllll}2 & 3 & 4 & 5 & 6 & 7 & 8 & 9 & 20\end{array}$

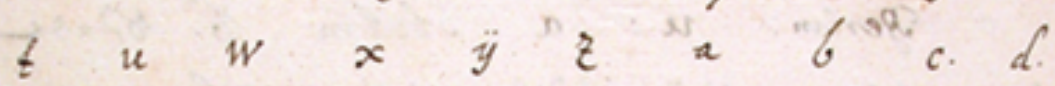

ii. is is it is. $26.2 \%$ 28. 29. 20.

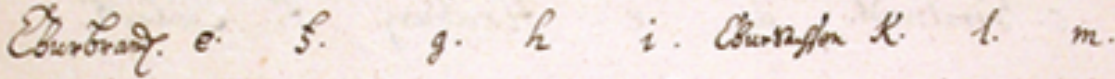

2i. $22 \cdot 23 \cdot 2 q \cdot 25 \cdot 26 \cdot 27 \cdot 28 \cdot 29 \cdot 30$. Corig in $n$. p. $q$. r. Somigin $t u$. 3i. 32. 33. $34 \cdot 35 \cdot 36$ 34. $38.39 \cdot 40$. 14. $x$ \& Reberae. $a$ e i. odlendors, $u$ $4^{i} t^{2} \cdot 4^{3} \cdot 4 t^{2} \cdot t^{6} \cdot 47 \cdot 4^{8} \cdot 49 \cdot 50$. a. $b$ c. d e floofling $g$. $k$. si. su. sy. sq. ss. s6. sy. s.8. sg. Go. Hawwif $i$ K. l. m. Rothrax $n$. 0 .

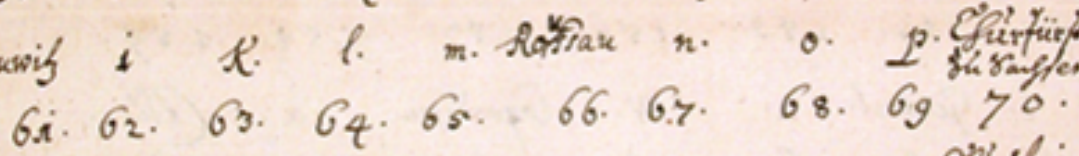

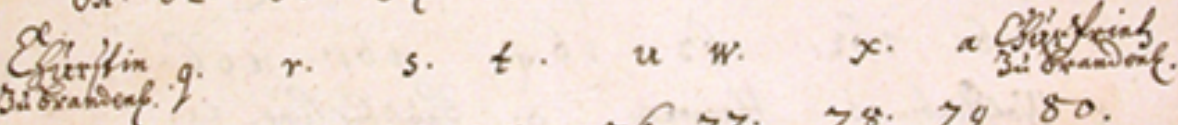
yi. $7^{2} \cdot 7^{3} \cdot 74 \cdot 7^{5} \cdot 7^{6} \cdot 77 \cdot 7^{8} .7980$. c. $i$ o. Reginest u. a. Regimat b. c. Eajifer81. 82. 83. $84.85 \cdots 86.87 .88 .89 .90$.

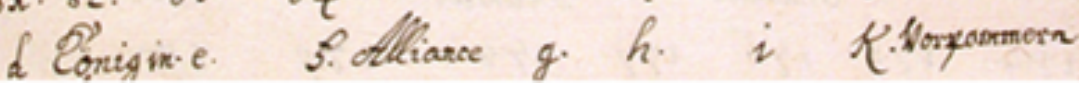

A listing of all numbers with their significance was needed for deciphering

\begin{tabular}{cccccccccc}
\hline $\mathrm{L}$ & $\mathrm{m}$ & $\mathrm{n}$ & Armee & $\mathrm{o}$ & $\mathrm{p}$ & $\mathrm{q}$ & Schwed.Flotte & $\mathrm{r}$ & $\mathrm{s}$ \\
1 & 2 & 3 & 4 & 5 & 6 & 7 & 8 & 9 & 10 \\
\hline
\end{tabular}

Figure 9. One of two parts of the Nomenclator from the time of the reigning two sons of Duke August, dated 1683 and issued to their Chancellor, "Präsident von Heimburg": Clavis solvens for deciphering (the original page 45). 


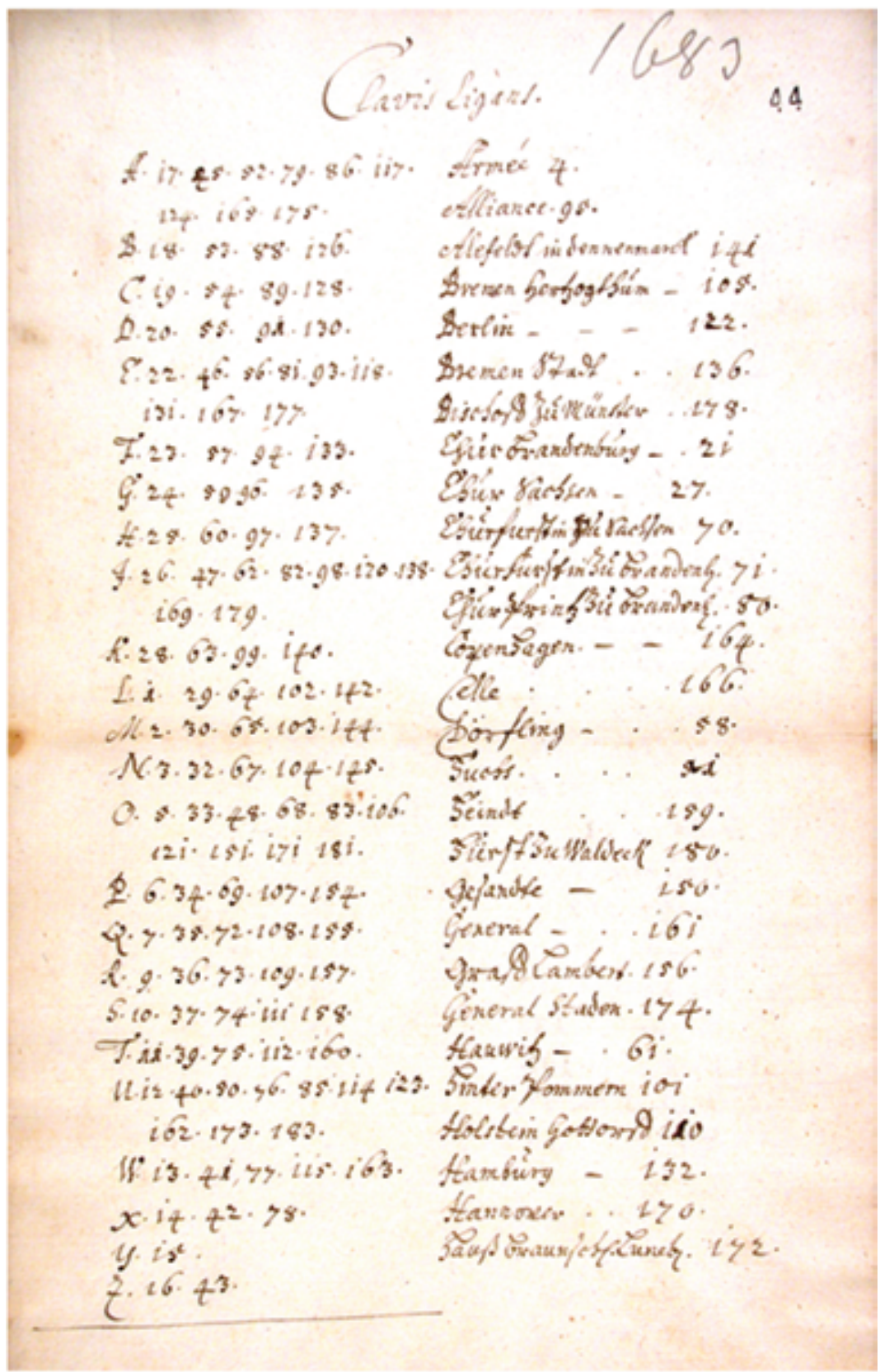

FiguRE 10. An example of a page from a Nomenclator from 1683 from the Wolfenbüttel Chancery. Here the key for deciphering - Clavis ligans. The individual plaintext words are doubly assigned: "Armée" with the code number "4" (right) as well as with a longer number combination (to the left): "A. 17. 95 (?). 82. 79. 86. 117 ", to be used alternatingly. 
investigation is greatly facilitated by the excellent and erudite English translation that John William Henry Walden had to prepare in advance of DurningLawrence's authorship attribution. ${ }^{37}$ Such Baconians are particularly interested in the attractive title page, and if they ever saw Duke Ferdinand Albrecht's own copy they certainly overlooked his $\mathrm{Nb}$ above his father-and his holding of the "crown of honor" over none other but Trithemius's head (Fig. 11, p. 201),

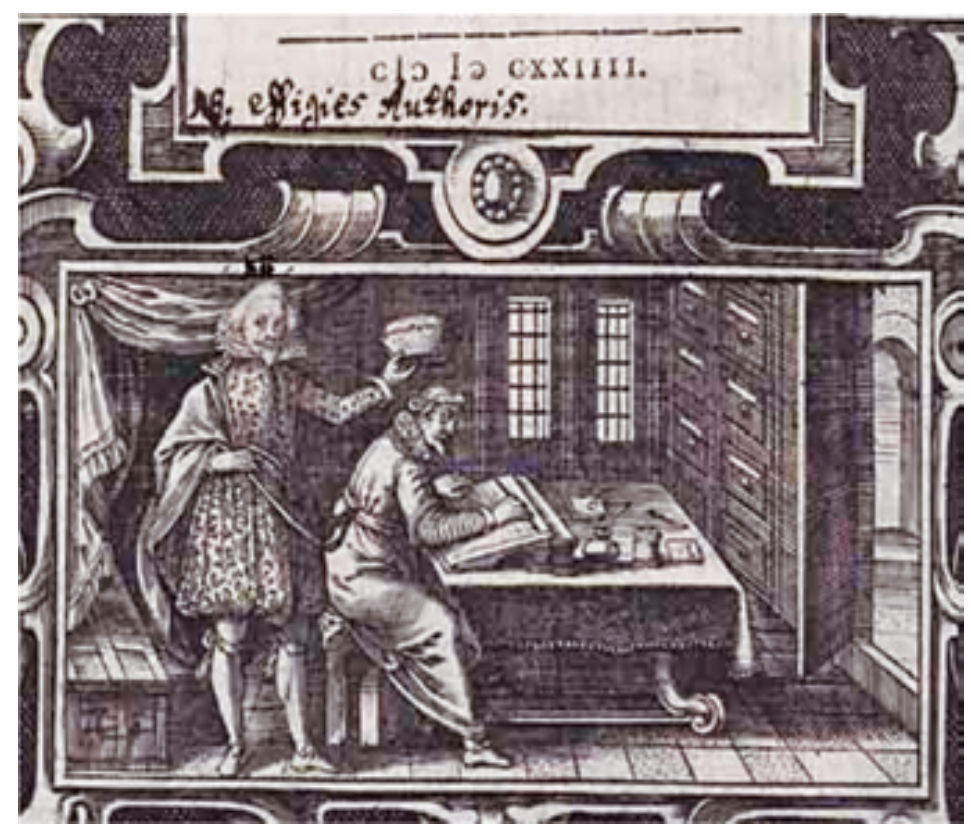

Figure 11. Detail: The NB "effigies Authoris" is placed right over the head of a portrait of well-dressed, balding Duke August, represented with his characteristic pointed beard. In the illustration he is holding a kind of crown of honor over the head of Trithemius, who is shown writing at a desk (exactly as in the instructions to Lucas Kilian).

as spelled out in Duke August's instructions. To the very contrary DurningLawrence's book reprints a clean title page of Cryptomenytices along with enlarged plates reproducing its four distinct sections - and its author sees in the duke's likeness that "of an actor, very much overdressed and wearing a mask something like the accepted mask of Shakespeare". ${ }^{38}$ No need to say more-During-Lawrence's chapter reference may suffice as an ending to this analysis, namely "Love's Labour's Lost" - to quote none other than the real Shakespeare.

\footnotetext{
${ }^{37}$ See above, f. n. 26.

${ }^{38}$ Durning-Lawrence (see [40, f. n. 36), p. 126.
} 


\section{Pictorial Supplement}

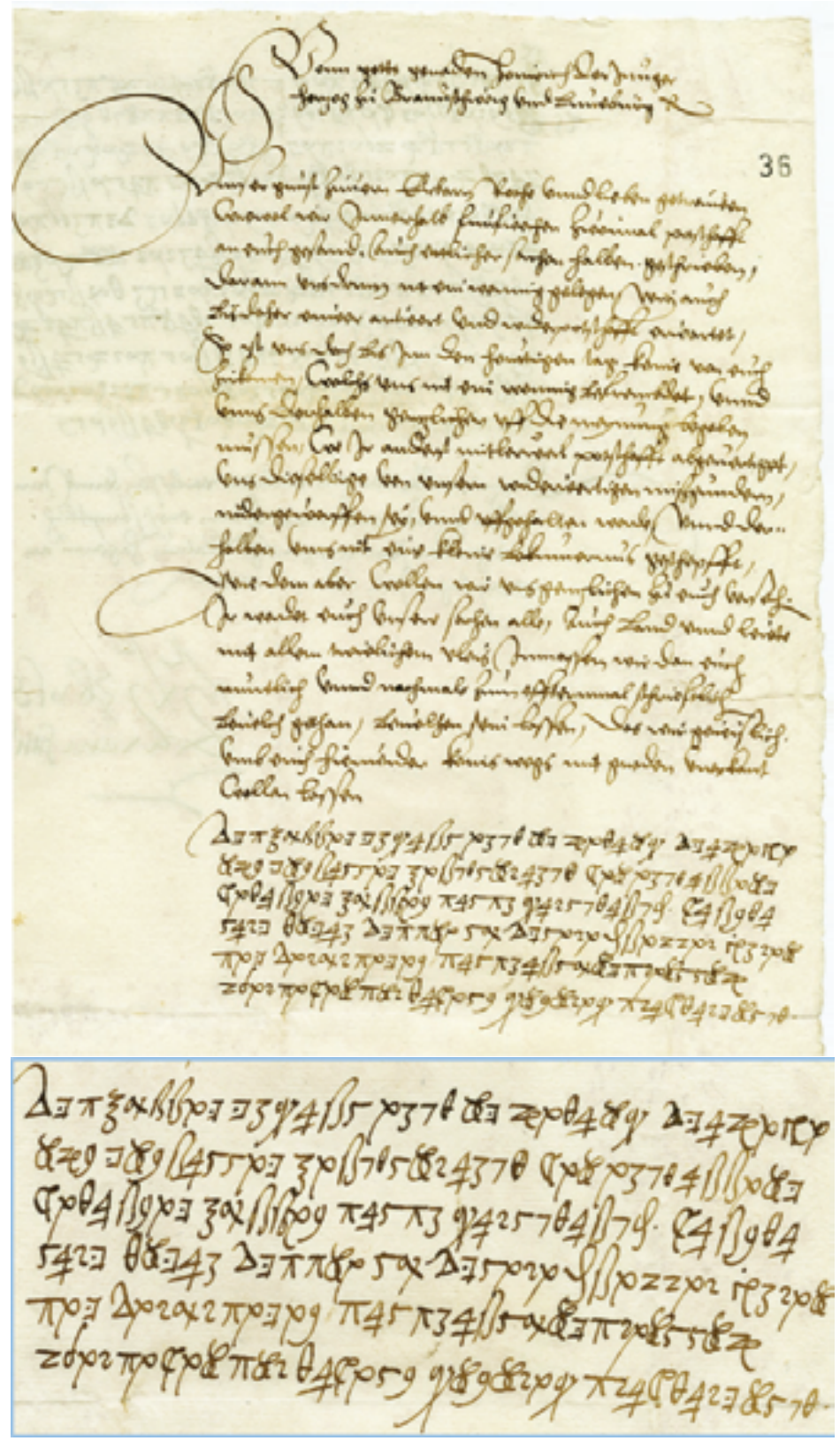

FIGURE 12. Letter of (Catholic) Duke Henry the Younger to Johann von der Asseburg concerning the suppression of the Schmalkaldic League and the Protestant Estates: Lower part of page is enciphered. 
GERHARD F. STRASSER

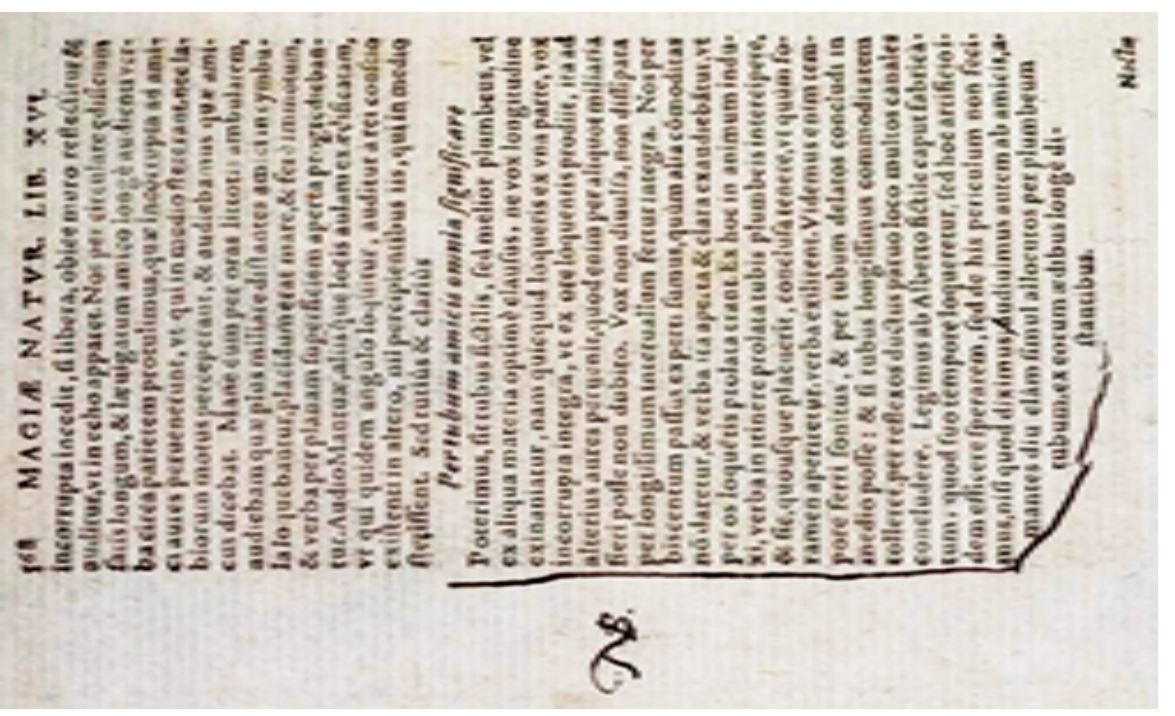

胥

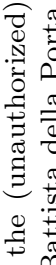

$\exists$.

호

을

हृํำ

㟧.

600

¿

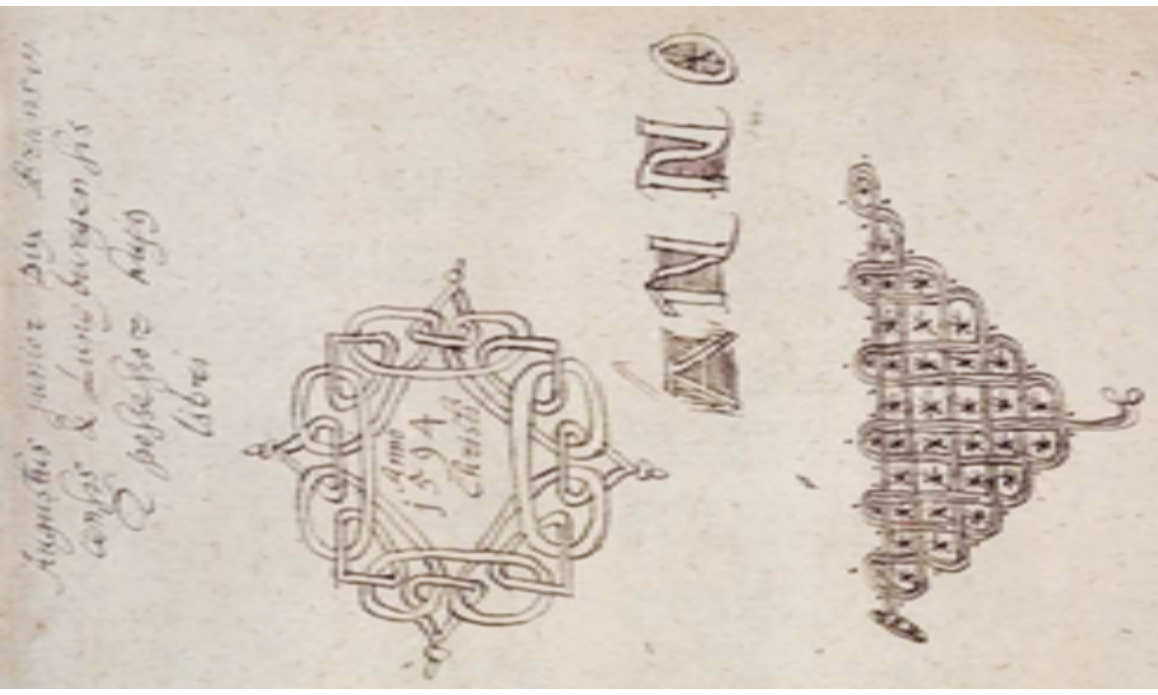

站要

귱

๘ี

15

땅

兒蒿

ซี

욜

ज्ञ

㐿

$\rightarrow$

斑 


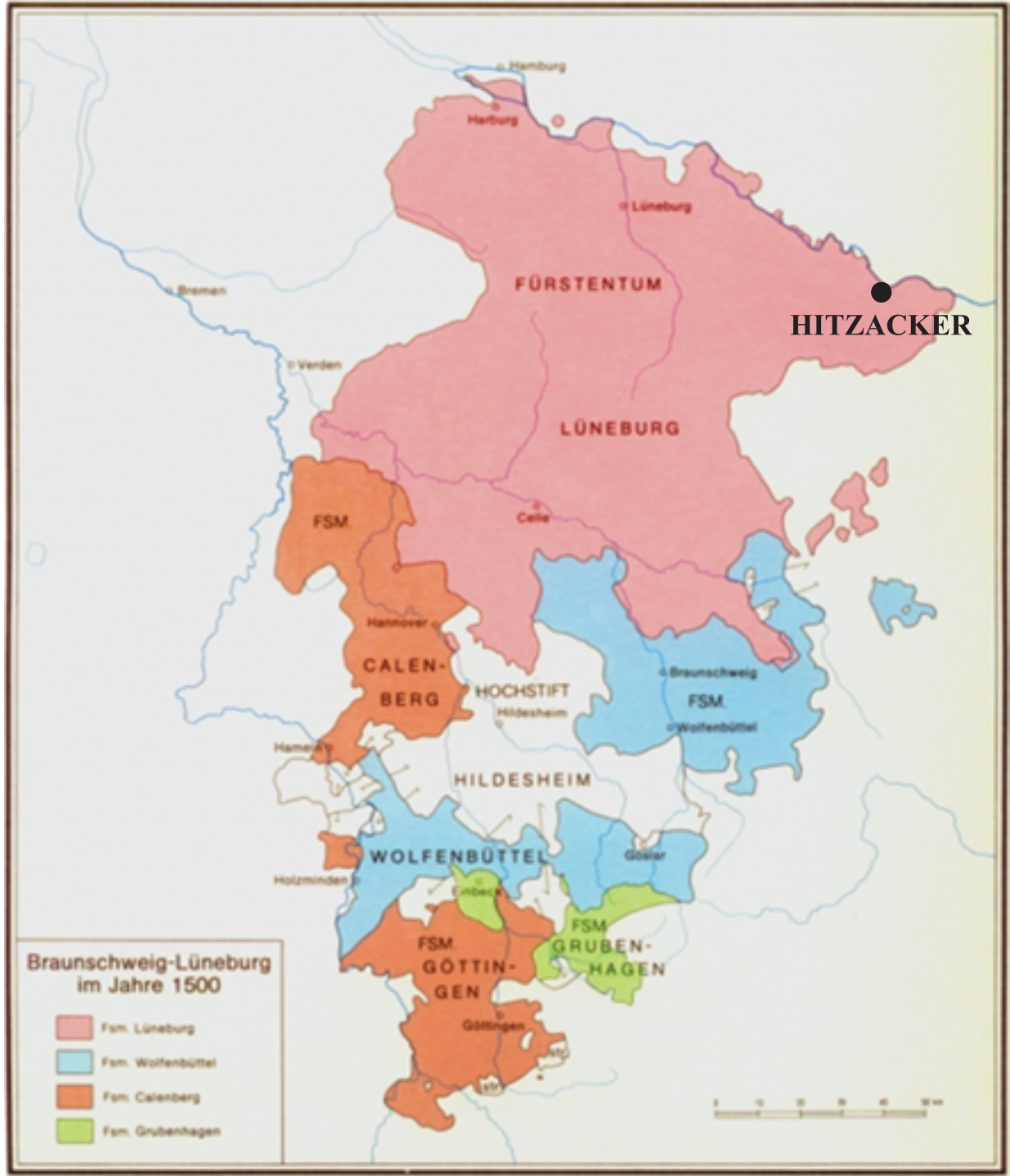

Figure 14. Location of the Tiny City and County of HITZACKER in a bend of the Elbe river, where Duke August "Resided" for over 30 Years before Becoming the Ruler of the Duchy of Brunswick-Wolfenbüttel. 


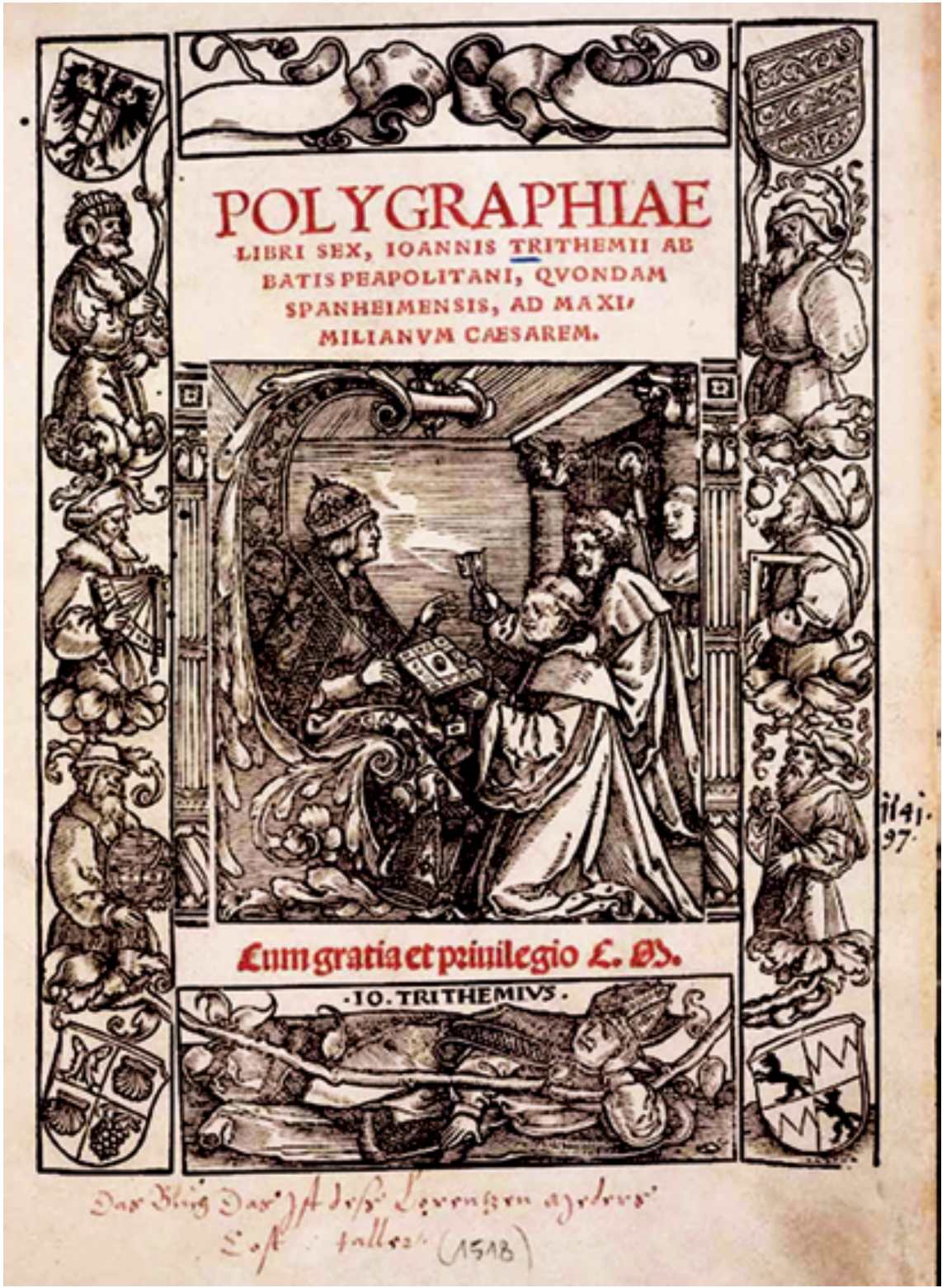

FiguRE 15. Title page of the Second cryptographic work of Johannes Trithemius, Polygraphiae libri sex, Published in 1518 (two years after the author's death), the first printed book exclusively devoted to Cryptographic systems.

Trithemius, kneeling in front of Emperor Maximilian I, is presenting his work to the Emperor. 
WOLFENBÜTTEL, CENTER OF CRYPTOLOGY IN THE EARLY MODERN PERIOD

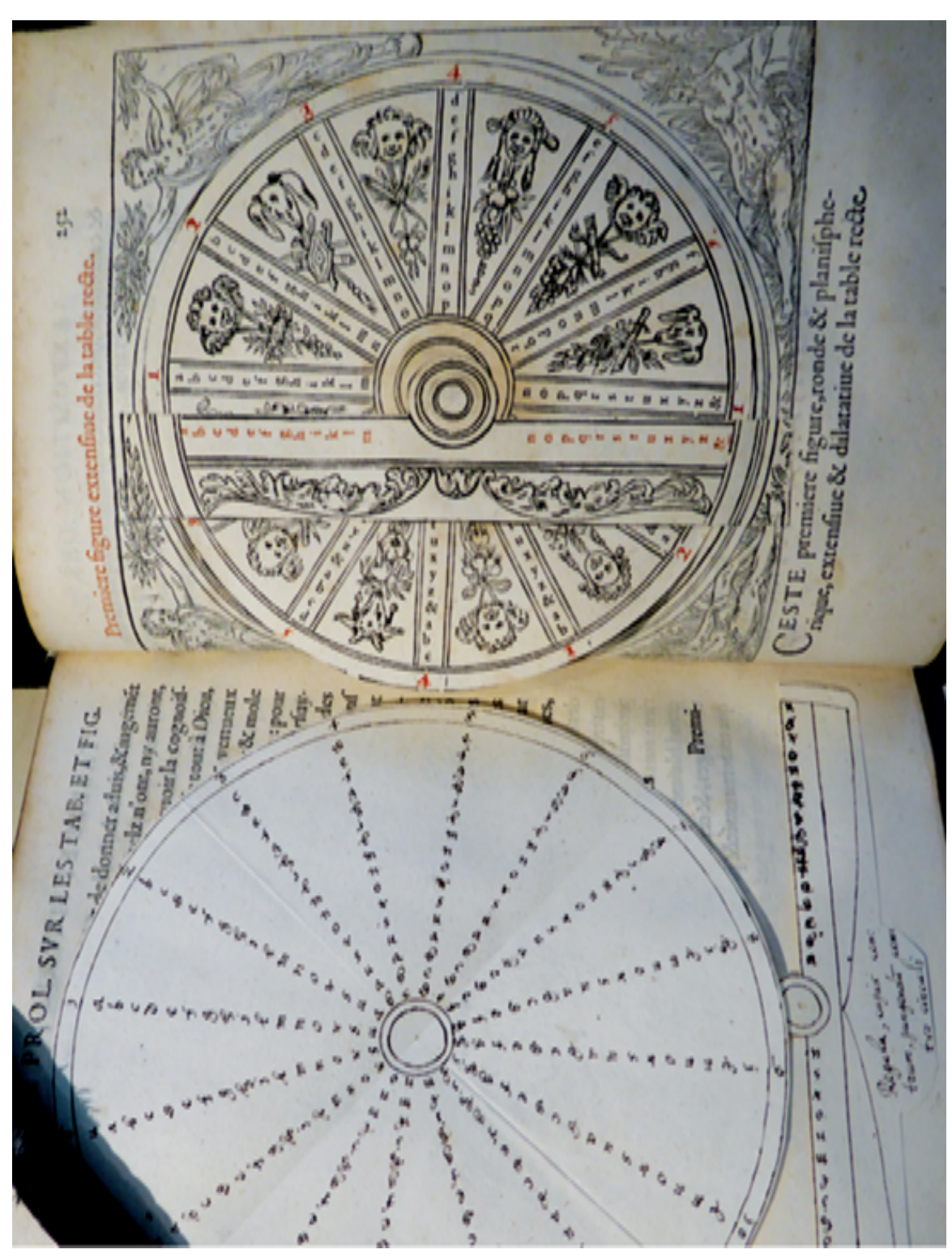

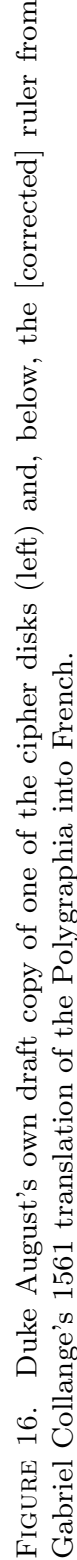



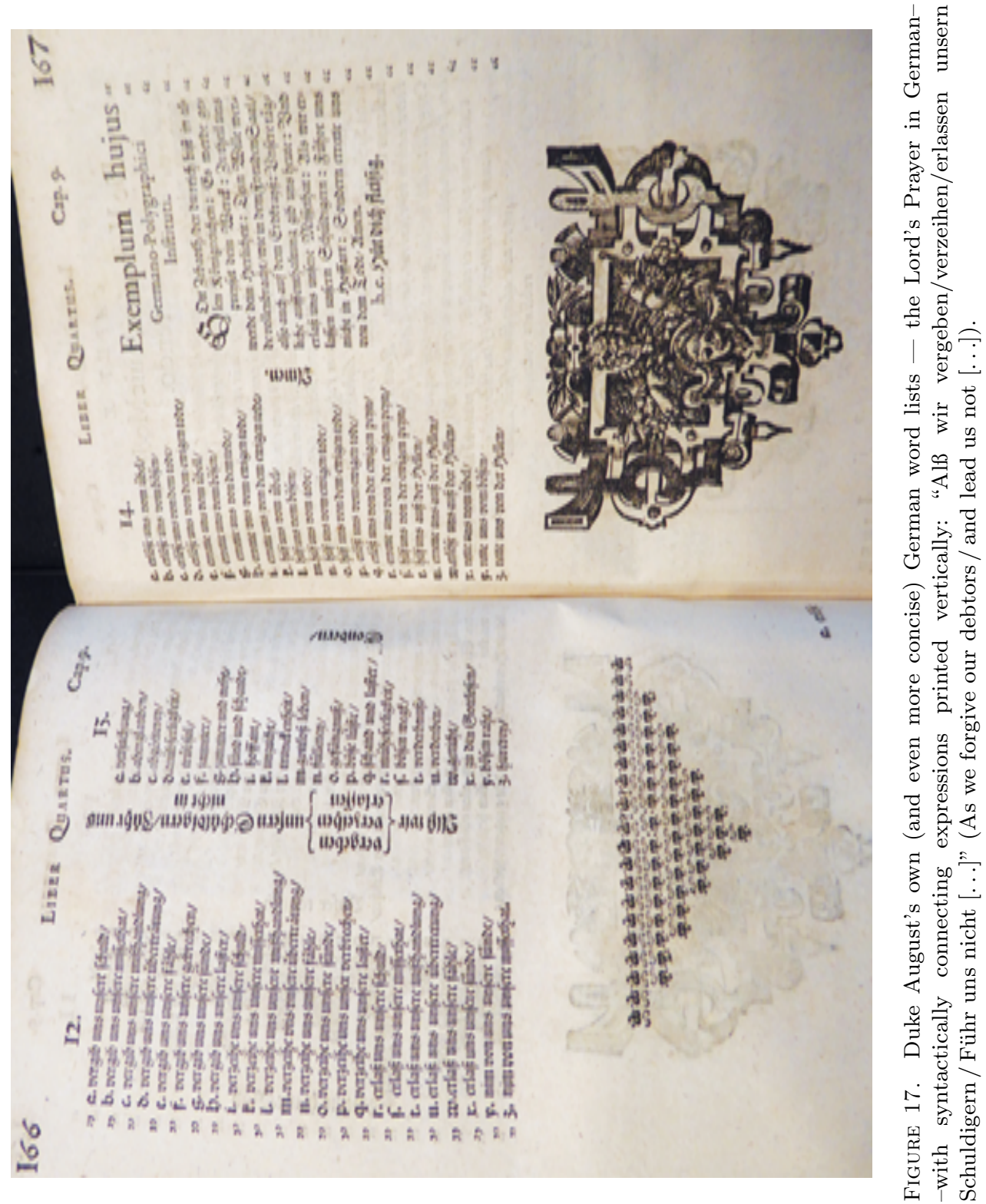


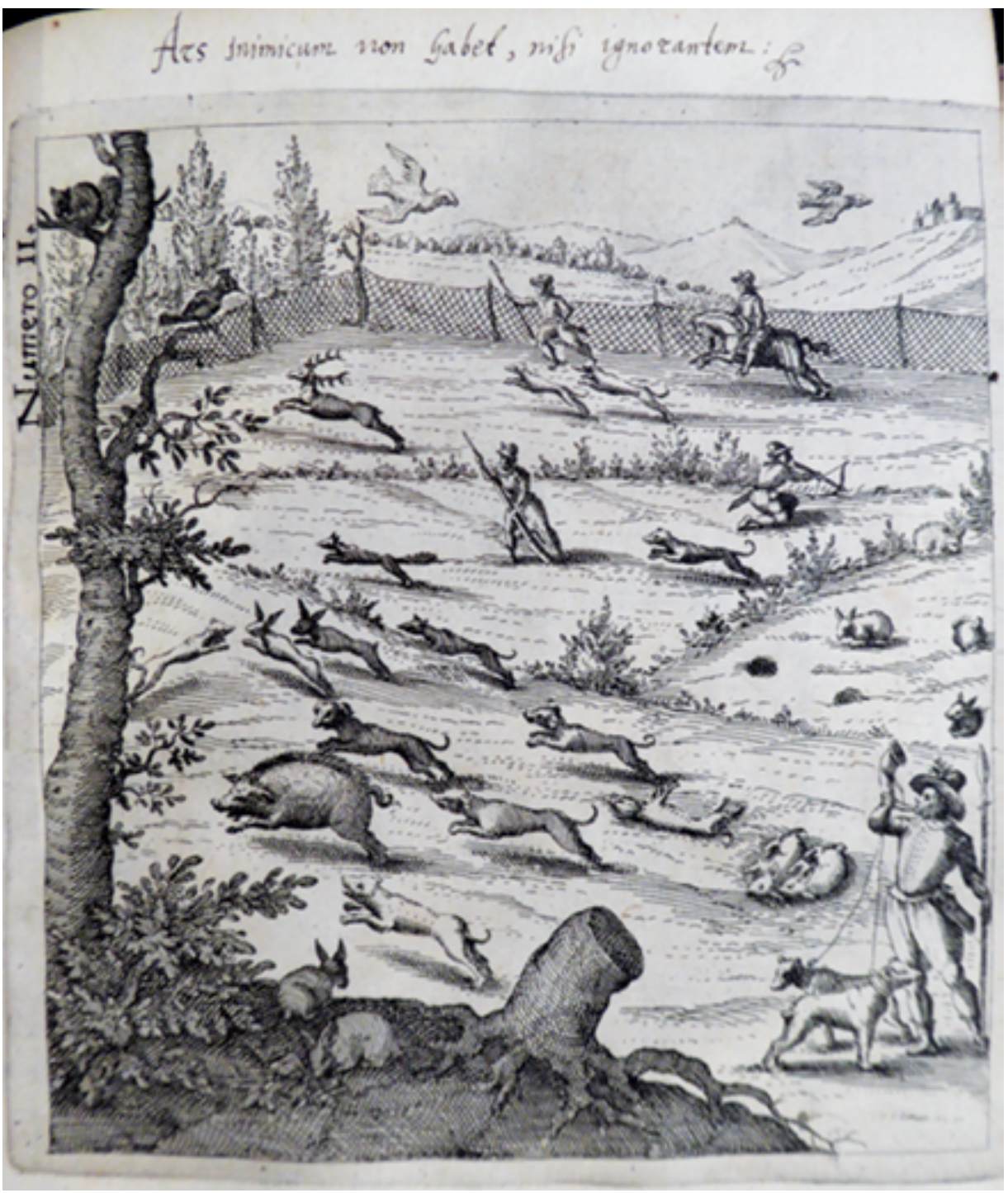

FiguRE 18. Johann Walch: Decas fabularum humani generis [...]. Strasbourg 1609. Example of a Dot Cipher: Steganographic Illustration of a Hunting Party, where the Eyes of the Animals and Hunters (the Dots) taken together encipher a message. Duke August deciphered it and wrote it over the engraving: "Ars inimicum non habet, nisi ignorantem" (Art has no enemy except for the ignorant ones). 
GERHARD F. STRASSER

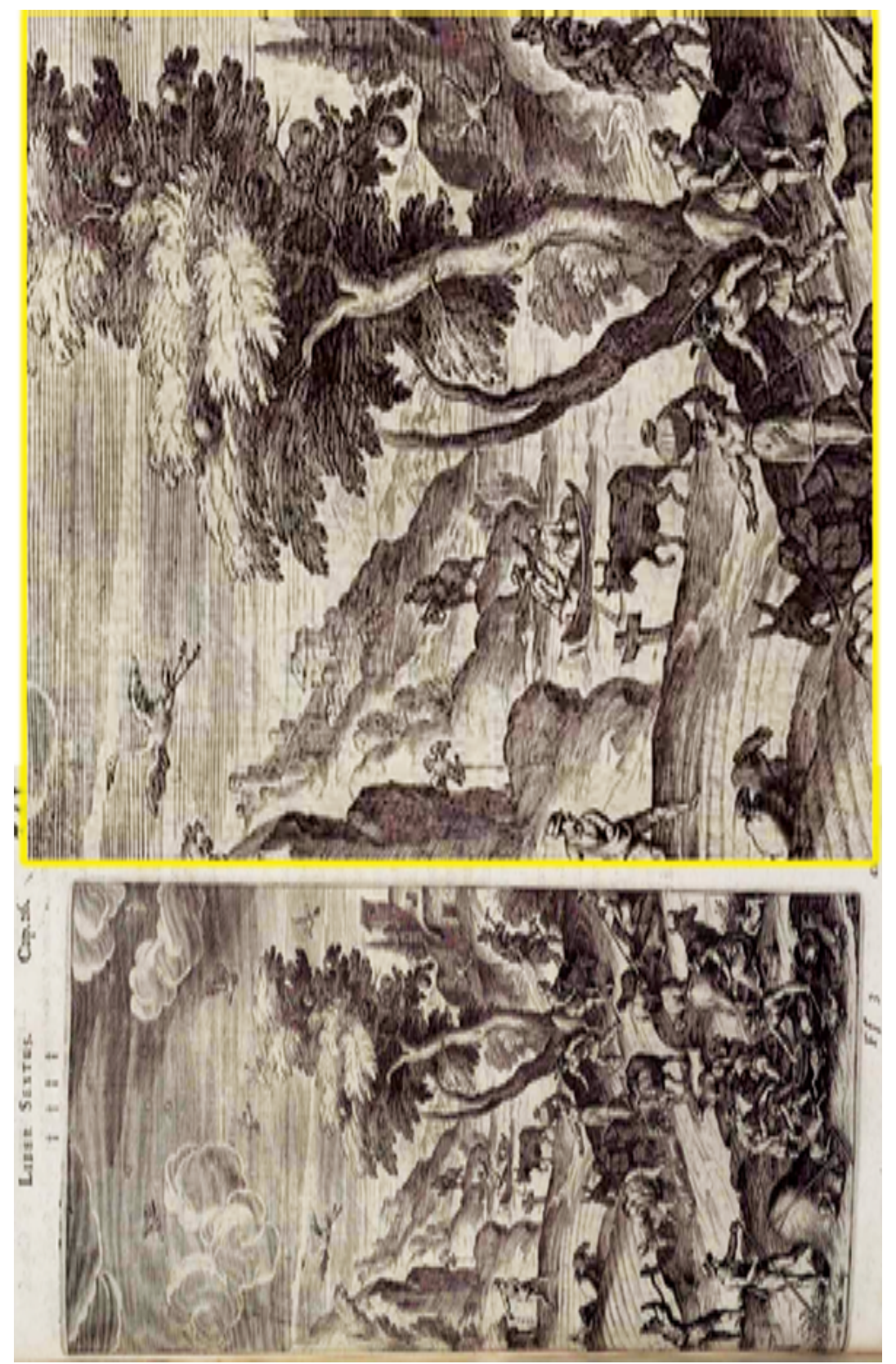

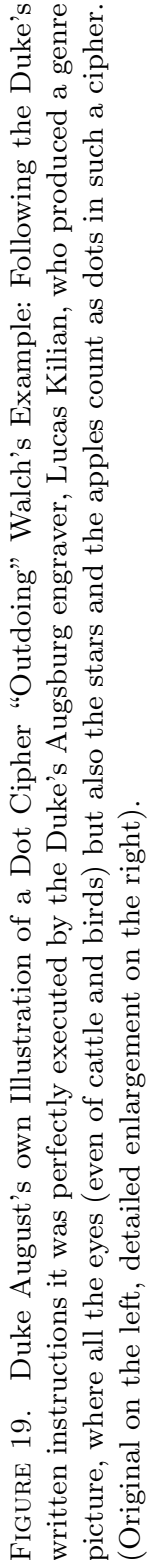


WOLFENBÜTTEL, CENTER OF CRYPTOLOGY IN THE EARLY MODERN PERIOD

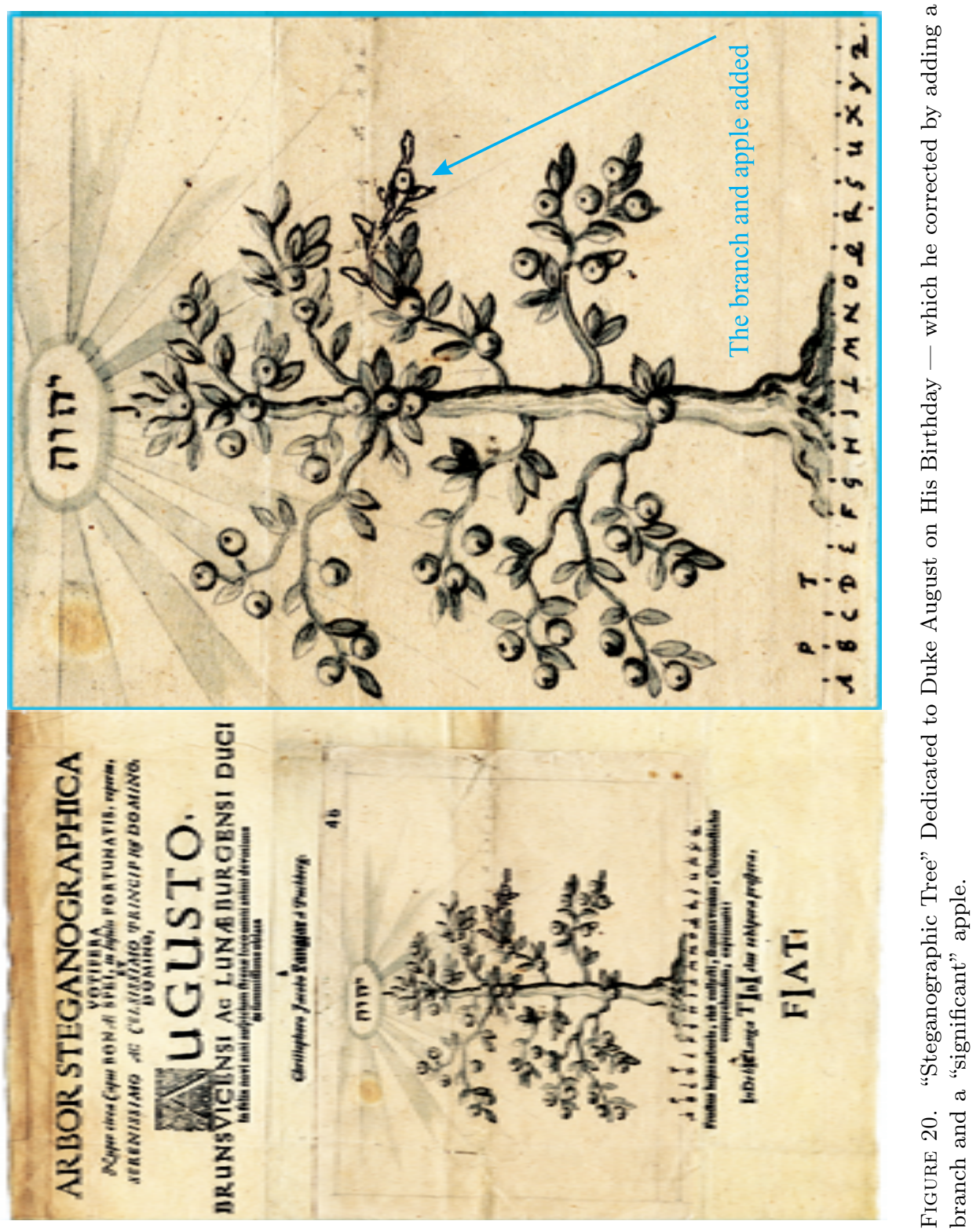


GERHARD F. STRASSER

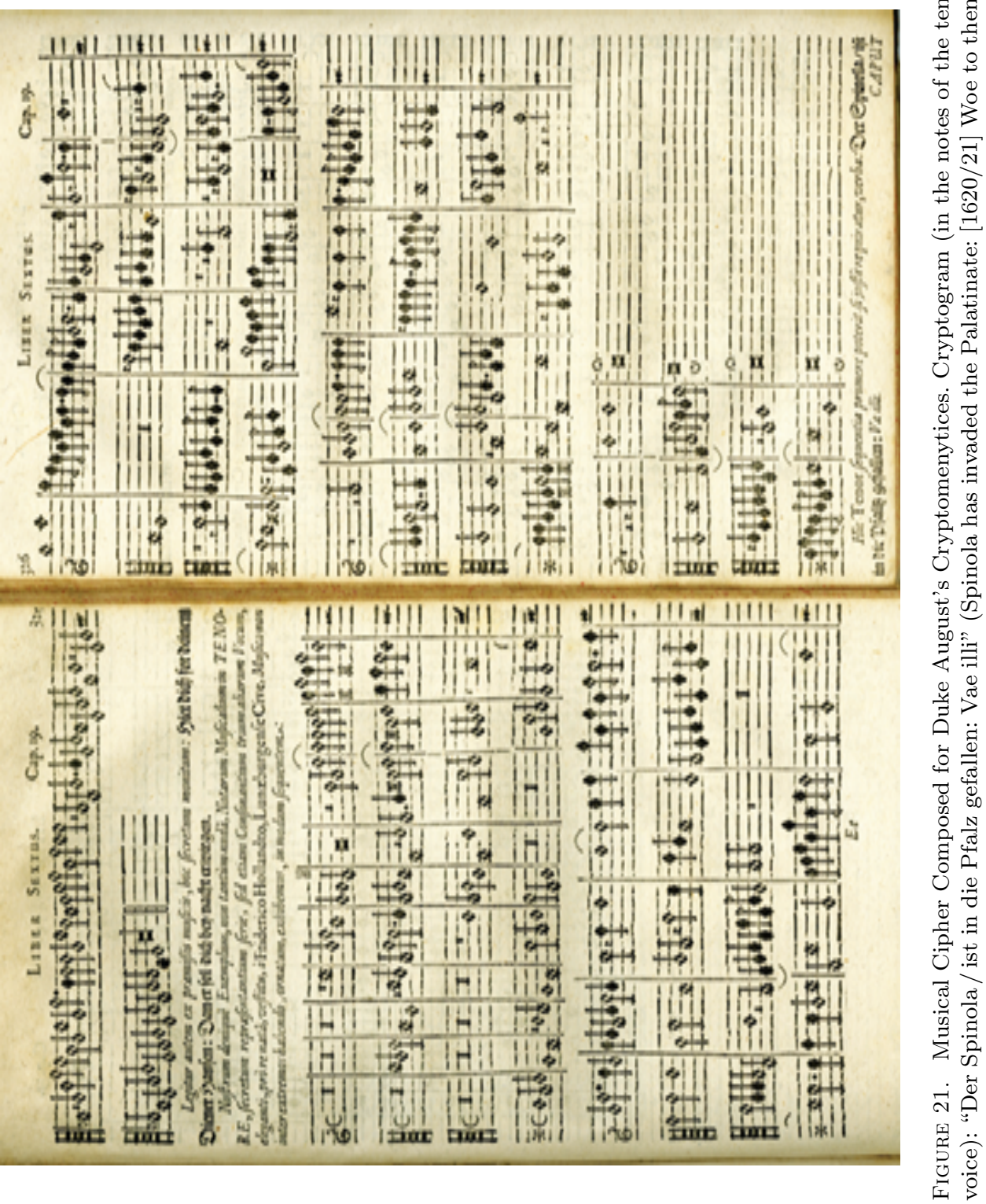



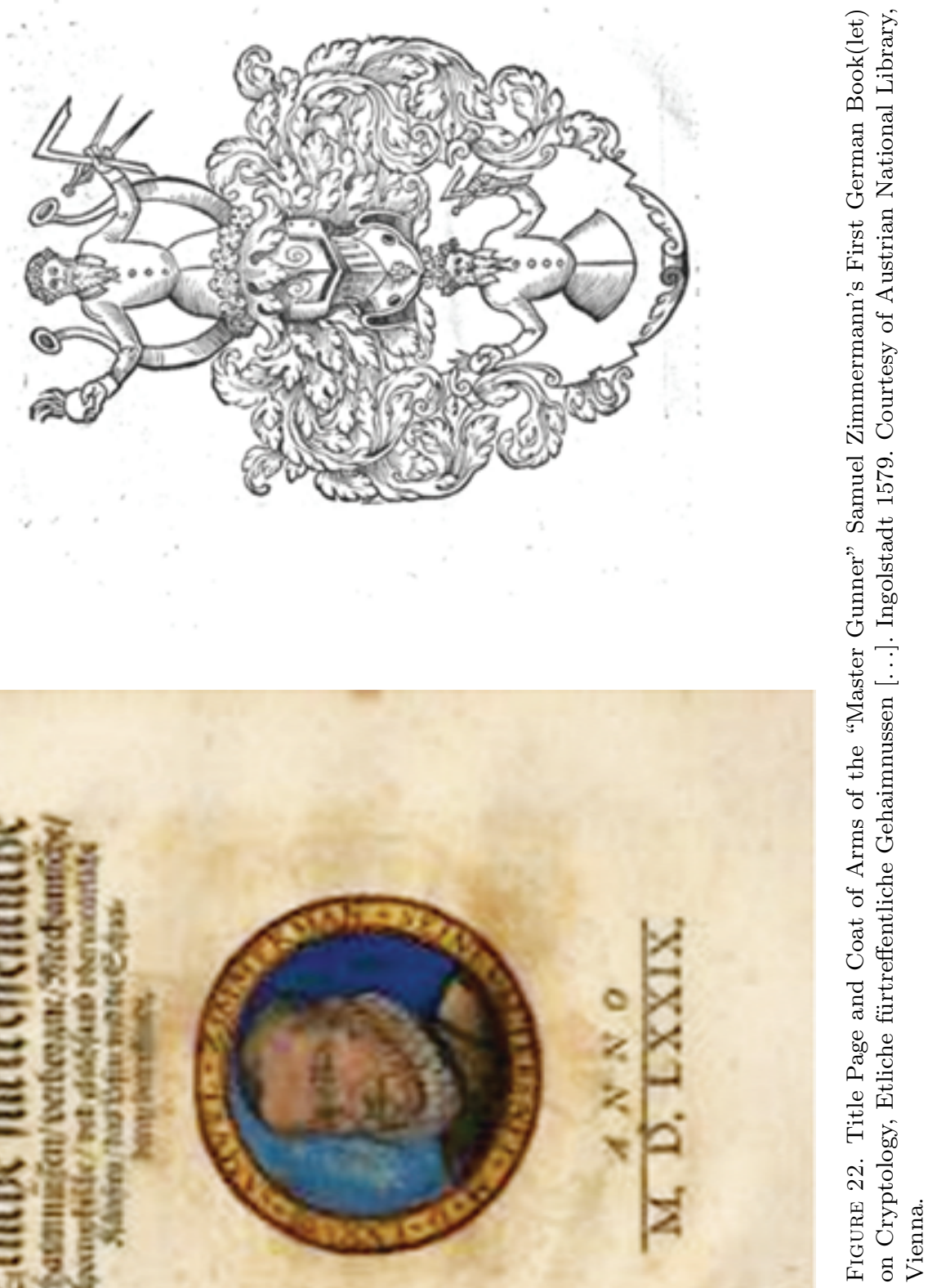


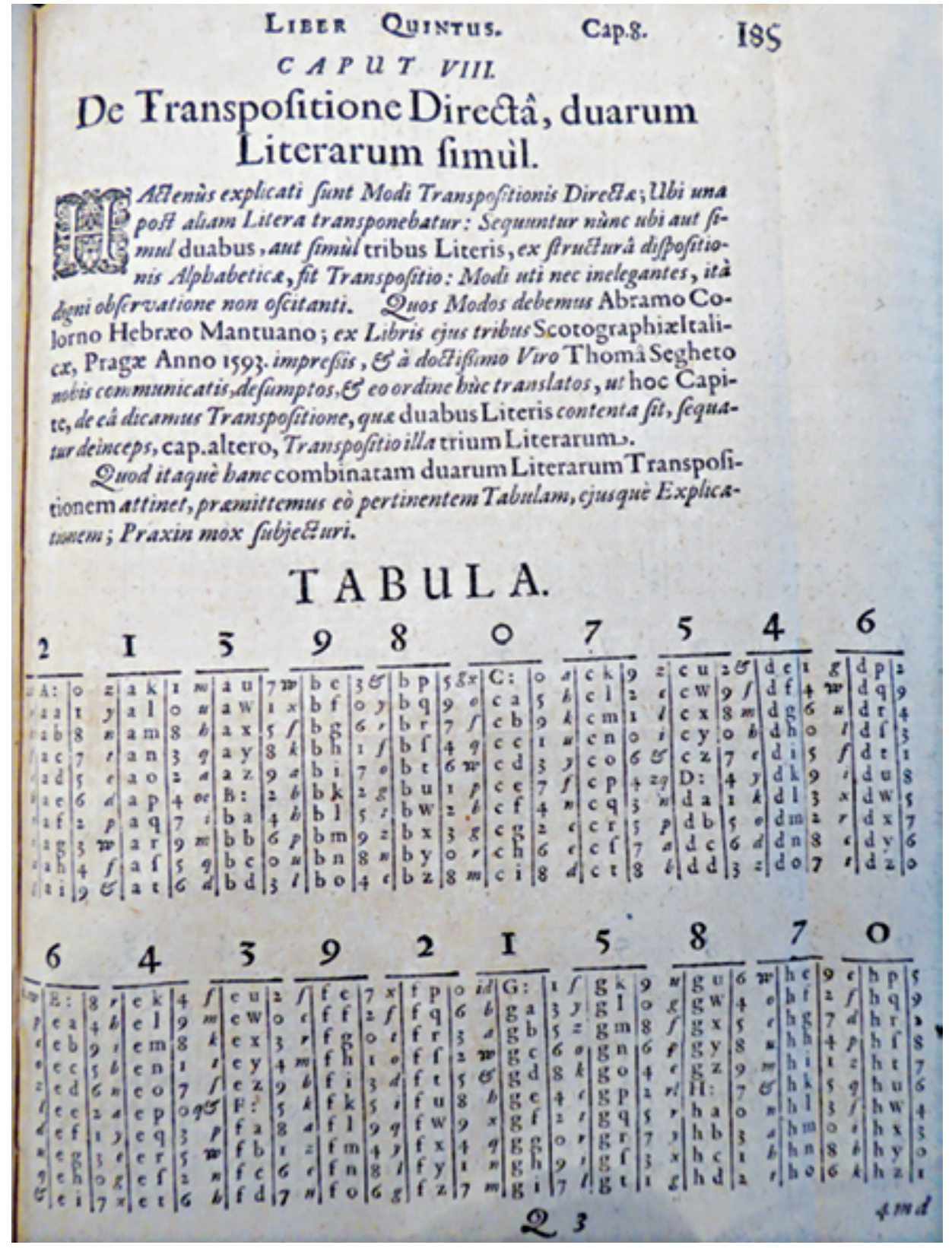

Figure 23. Beginning of 60 pages of "Transposition Tables" in Duke August's Cryptomenytices, taken from Abramo Colorni's ("the Jew of Mantua", as he called himself) 1593 Scotographia. Prague: Schumann. 


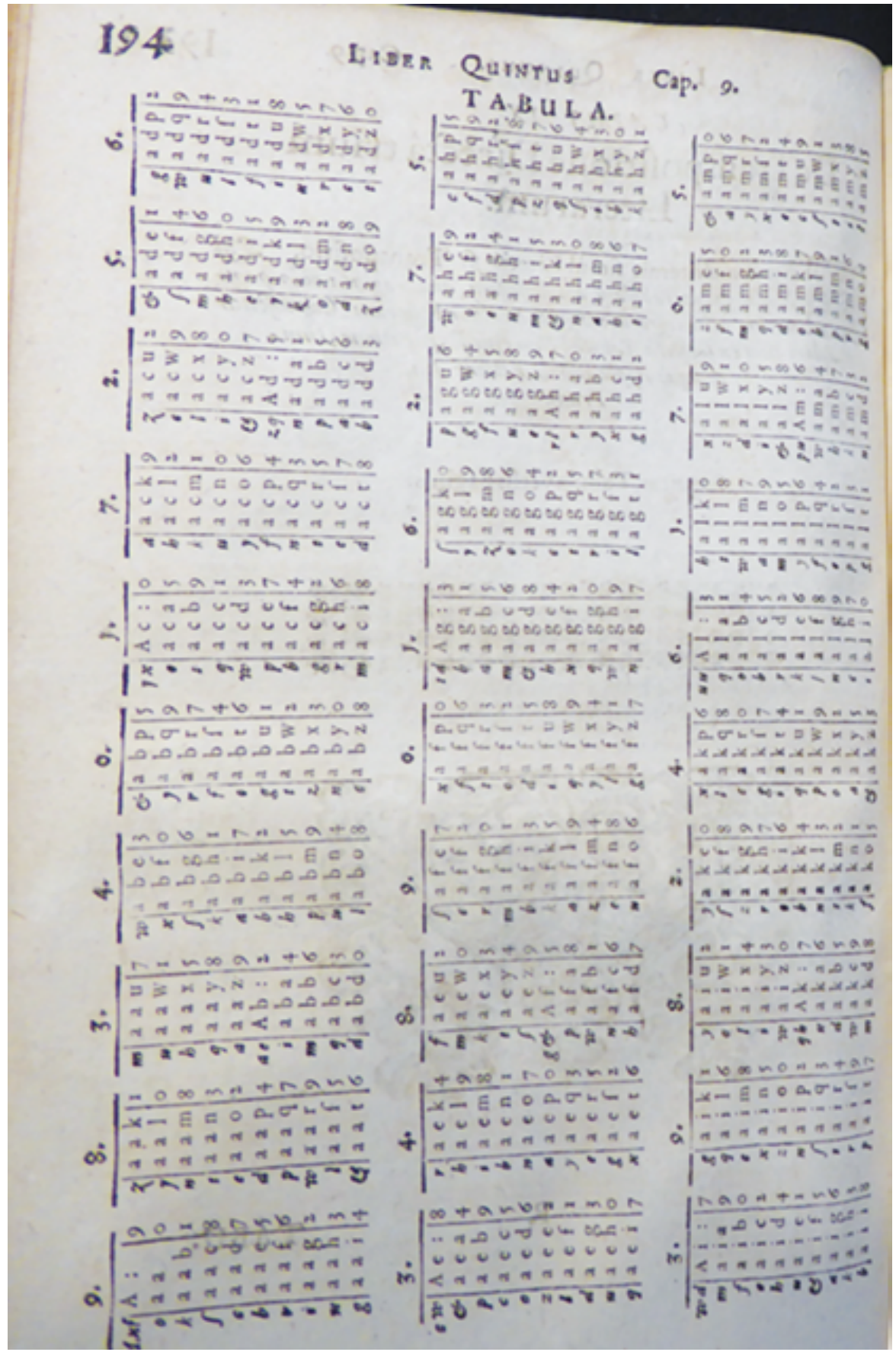

Figure 24. Sample page in Cryptomenytices of Colorni's Scotographia (p. 194). 


\section{GERHARD F. STRASSER}

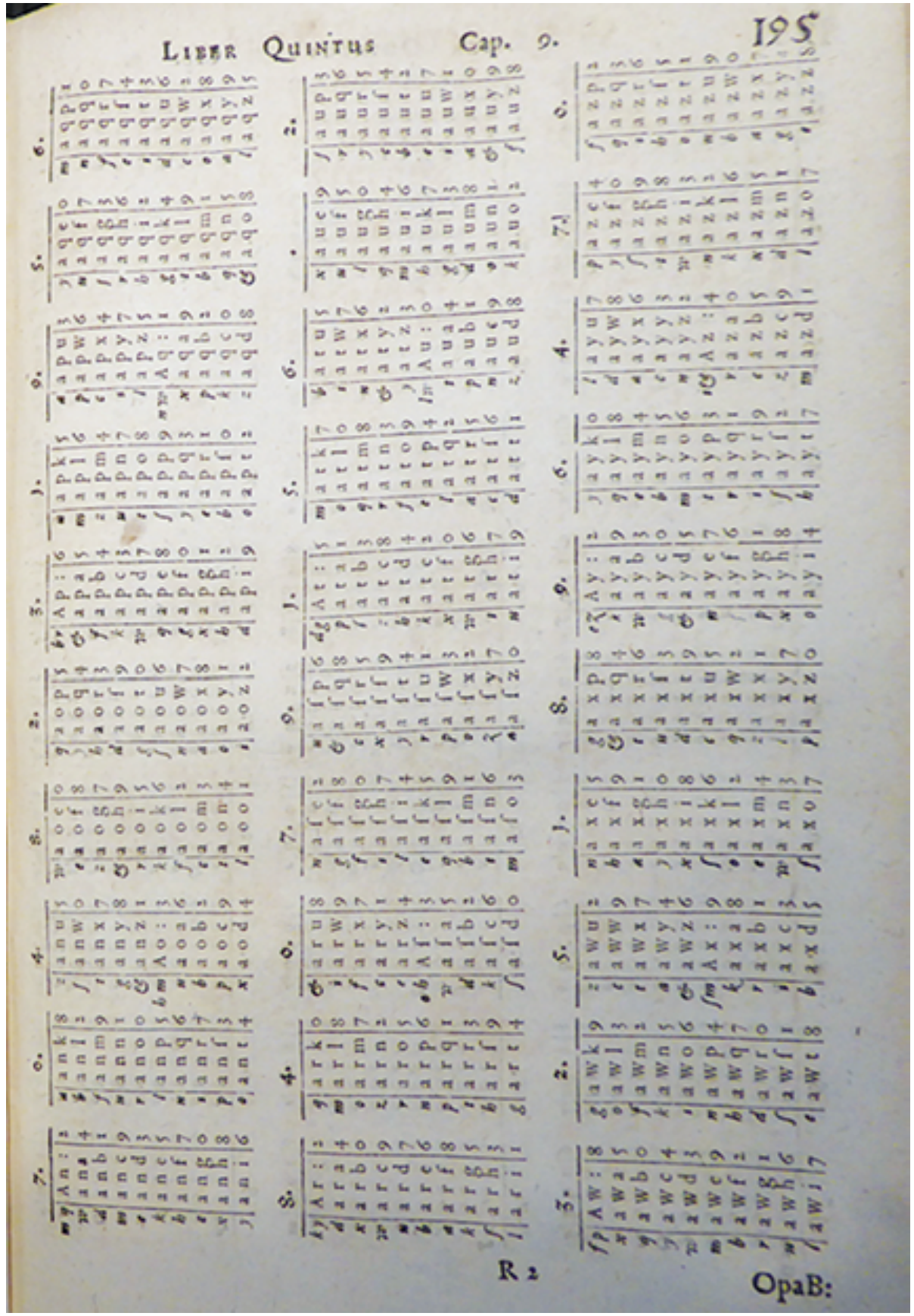

Figure 25. Another sample page in Cryptomenytices of Colorni's Scotographia (p. 195). 
WOLFENBÜTTEL, CENTER OF CRYPTOLOGY IN THE EARLY MODERN PERIOD
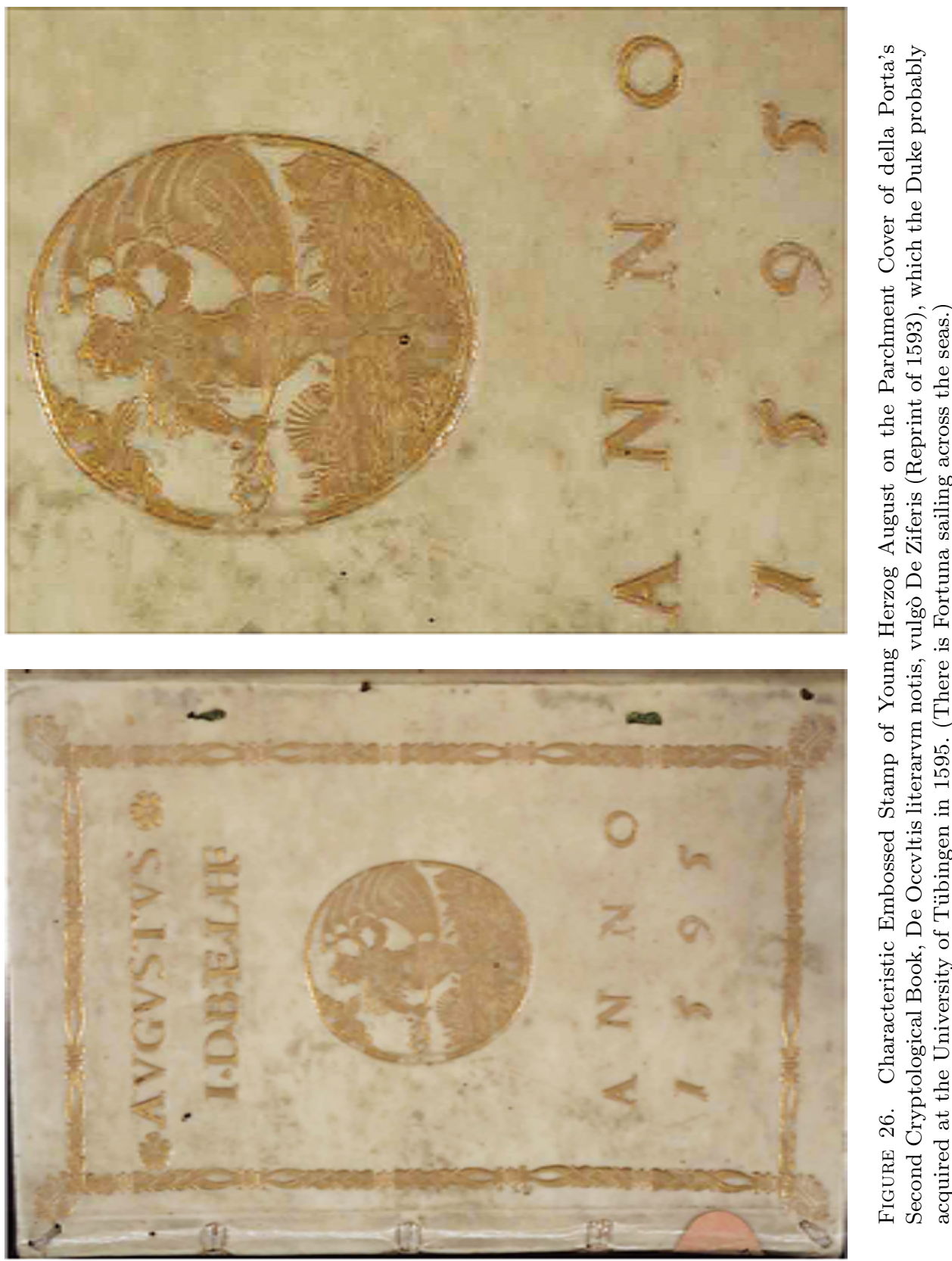

की

궁 응

虫

2.

द्व

贾: : $:$.

త

至

응 :

द्वे

0 莒

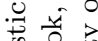

娄

तี

สี .5

응 응

웅

丽焉

될 응

范

○ 仓 
GERHARD F. STRASSER

를

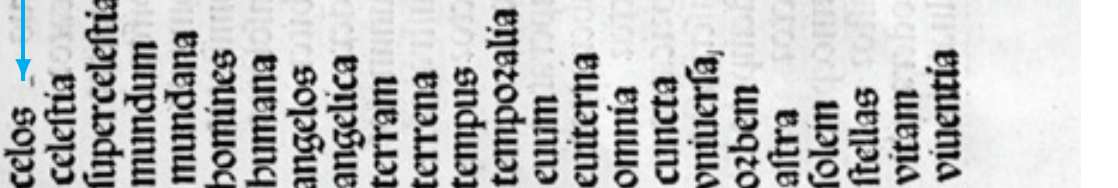

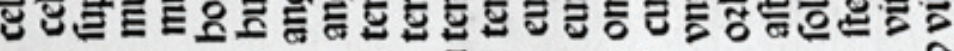

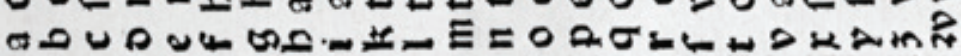

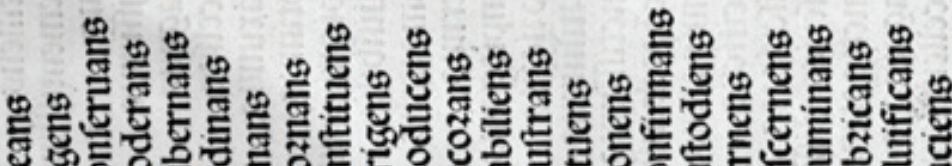
혼 ตค
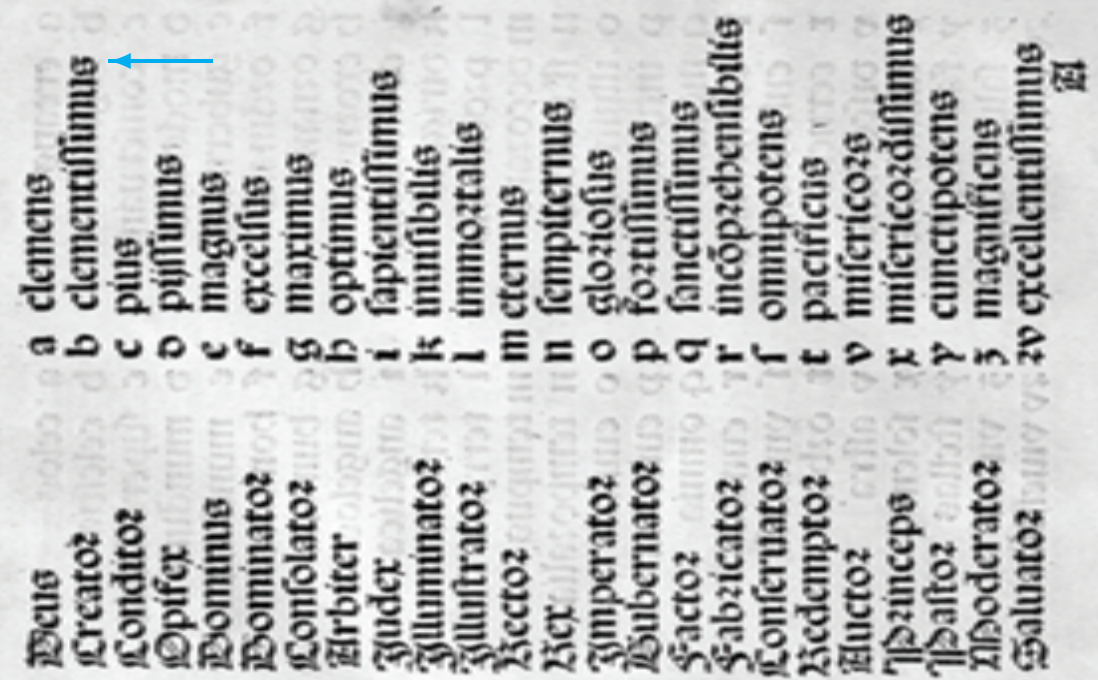


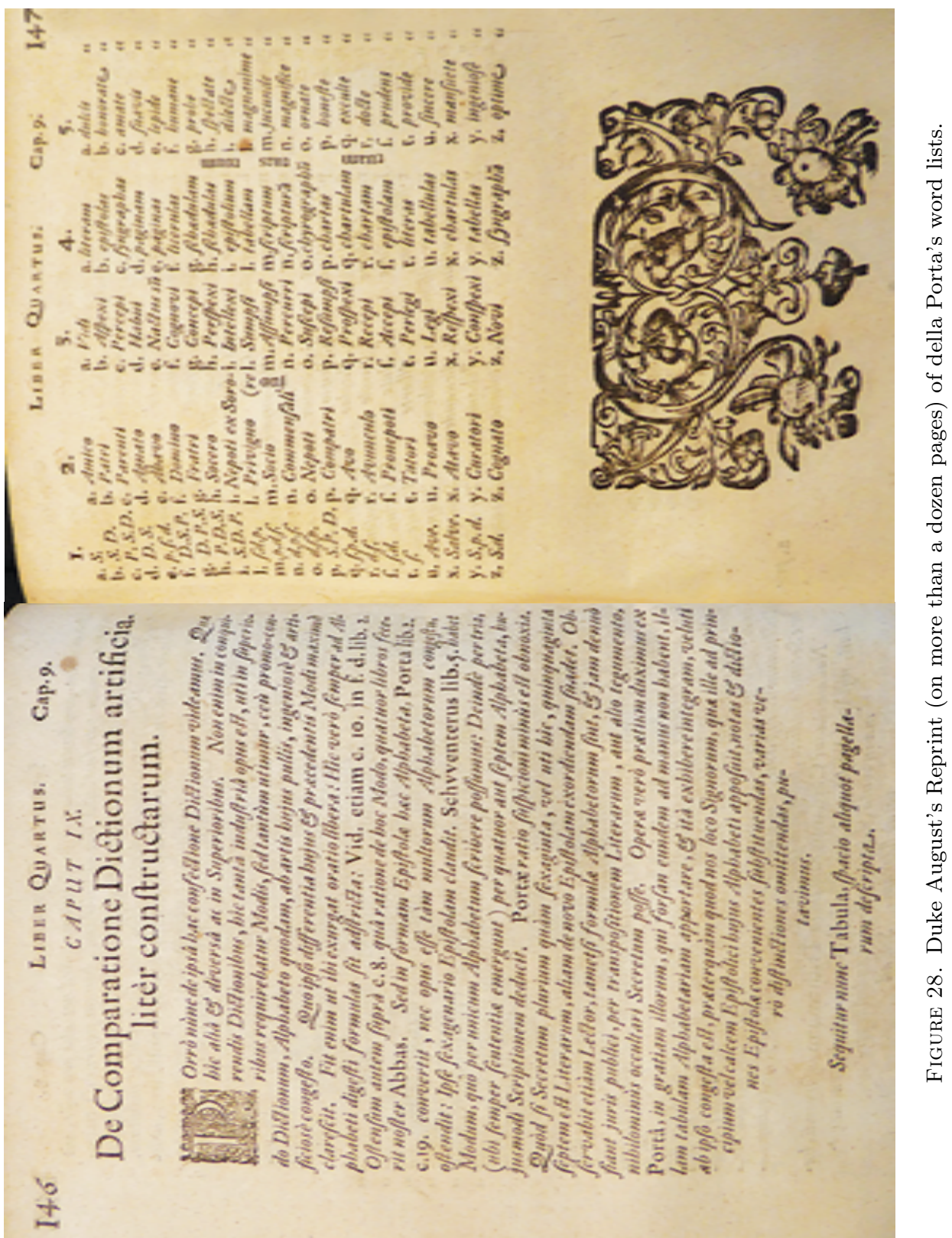




\section{GERHARD F. STRASSER}

\section{REFERENCES}

[1] DUKE AUGUST THE YOUNGER: (Gustavus Selenus, pseudonym), Cryptomenytices et Cryptographiae Libri IX. Gebrüder, Stern, Lüneburg, 1624.

[2] STRASSER, G. F.: Duke August the Younger of Brunswick-Luneburg (Gustavus Selenus) and his cryptological activities. Cryptologia Vol.7 (1983), pp. 193-217.

[3] STRASSER, G.F.: Geheime Schriften im Staatsarchiv: Kryptografie oder die Kunst, Geheimes zu verbergen und zu entschlüsseln. Braunschweigisches Jahrbuch für Landesgeschichte Vol. 91 (2010), pp. 85-109.

[4] Wikipedia (accessed 03/23/201), https://de.wikipedia.org/wiki/Heinrich_II._(Braunschweig-Wolfenb\%C3\%BCttel)

[5] Niedersächsisches Staatsarchiv Wolfenbüttel (NLA-STA WF), 1 Alt 8.

[6] NLA-STA WF, 1 Alt 8, Nr. 490, BL. 36 rº.

[7] STRASSER, G. F.: Duke August (f. n. 1), pp. 197-201.

[8] DELlA PORTA, G. B.: Magia Natvralis [...]. Marne and Aubry, Frankfurt/Main, 1591, p. 56.

[9] DUKE AUGUST THE YOUNGER: (Gustavus Selenus, pseudonym), Cryptomenytices (f. n. 1), fol. b1 $\mathrm{r}^{\circ}-\mathrm{b} 2 \mathrm{v}^{\circ}$.

[10] DUKE AUGUST-VAN DER HEYDEN, J.-DE LANDAU, H.- BAROZZI, F.ROSENWALD, L. J.: Das Schach- oder König-Spiel [...]. Henning Groß d. J., Leipzig, 1616.

[11] ARNOLD, K.: Johannes Trithemius (1462-1516), Quellen und Forschungen zur Geschichte des Bistums Würzburg Vol. 23 (2nd ed.). Schöningh, Wiesbaden, 1991.

[12] STRASSER, G. F.: Lingua Universalis: Kryptologie und Theorie der Universalsprachen im 16. und 17. Jahrhundert. Wolfenbütteler Forschungen Vol. 38, Harrassowitz, Wiesbaden, 1988.

[13] TRITHEMIUS, J.: Steganographia: Hoc est: Ars per Occultam Scripturam Animi sui Voluntatem Absentibus aperiendi certa. Berner, Frankfurt, 1606; Polygraphiae libri sex [...]. Haselberg, Basel, 1518.

[14] DUKE AUGUST THE YOUNGER: (Gusavus Selenus, pseudonym), Cryptomenytices (f. n. 1), pp. 119-129.

[15] KAHN, D.: The Codebreakers The Story of Secret Writing. Reprint, rev. and updated. Scribner, New York, 1996, p. 154. (Brief mention of Duke August's work).

[16] STRASSER, G.F.: The Rise of Cryptology in the European Renaissance. In: (Karl de Leeuw, Jan Bergstra, eds.) The History of Information Security: A Comprehensive Handbook. Elsevier, Amsterdam, 2007, pp. 277-325.

[17] ALBERTI, L. B.: Trattato di Leon Battista Alberti Sulla Cifra. (Manuscript kept at the Vatican Library, Ms. Vat. Chig. M II 49). In: Alberti's Opuscoli morali [...], Francesco Franceschi, Venice, 1568.

[18] Collange, G.: Polygraphie et Vniverselle escriture Cabalistique de M. I. Tritheme Abbé [...]. Kerver, Paris, 1561.

[19] ZIMMERMANN, S.: Etliche fürtreffentliche Gehaimnussen [...], 2nd part of New Titularbuech: Das ist, Wie man ainer Jeden Person [...] zuschreiben soll. Published by the author, Ingolstadt, 1579, pp. 107-167. 


\section{WOLFENBÜTTEL, CENTER OF CRYPTOLOGY IN THE EARLY MODERN PERIOD}

[20] STRASSER, G. F.: Samuel Zimmermann's Gehaimnussen [...]. In: Cryptologia Vol. 40. 2016, pp. 240-260.

[21] DE SILVESTRIS, J.: Opvs Novvm [...] pro cipharis, lingua Latina, Graeca, Italica [...]. Rome, 1526.

[22] COLORNI, A.: Scotographia overo scienza di scrivere oscuro, facilissima, et sicurißima, per qual si voglia lingua [...]. Schuman, Prague, 1593.

[23] JÜTTE, D.: Geheimnisse übermitteln. Das Zeitalter des Geheimnisses: Juden, Christen und die Ökonomie des Geheimen (1400-1600). Vandenhoeck \& Ruprecht, Göttingen, 2011; Geheimnisse übermitteln (2nd ed.), 2012, pp. 258-268.

[24] HELIAS MONACHUS [FRANCISCANUS]: Opuscula quaedam chemica [...]. Bringer, Frankfurt, 1614. First English translation: The True Glass of Alchemy, 1597.

[25] CARDAnO, G.: De Rerum Varietate Libri XVII. Book 12, Ch. 61, Petri, Basel, 1557.

[26] DUKE AUGUST: (quotes Trithemius), Cryptomenytices (f. n. 1), fols. a3 v-a4 ro; (Walden, J. W. H.: translation of Duke August's entire book into English around 1900; https://archive.org/stream/TheCryptomenyticsAndCryptographyOfGustavusSelenus InNineBooks/Cryptomenytics\{\#\}page/n2/mode/1up (accessed 06/07/2017).

[27] STRASSER, G. F.: Die Europäische Rezeption der kryptologischen Werke Giovanni Battista Della Portas. In: Morgen-Glantz, Zeitschrift der Christian Knorr von RosenrothGesellschaft. Vol. 18 (2008), pp. 85-112.

[28] Della PORTA, G. B.: De Occvltis literarvm notis [...]. Foillet, Montbéliard, 1593, Book II, Ch. 1. and Ch. 19.

[29] DELla PORTA G. B.: De Fvrtivis Literarum Notis, vulgò De Ziferis Libri III. Scotus, Naples, 1563.

[30] DE SUNDE, J.H.: (pseudonym of Schwenter, Daniel), Steganologia \& Steganographia Aucta, Geheime / Magische Red vnnd Schreibkunst [. . ]. Halbmayer, Nuremberg, 1622(?), Book V.

[31] WALCH, J.: Decas Fabularum Humani Generis [...]. Zetzner, Strasbourg, 1609 (especially the 9th Fable).

[32] STRASSER, G.F.: Die kryptographische Sammlung Herzog Augusts: Vom Quellenmaterial für seine Cryptomenytices zu einem Schwerpunkt in seiner Bibliothek. In: Wolfenbütteler Beiträge Vol. 5 (1982), pp. 90-91 and p. 106.

[33] STRASSER, G.F.: Geheime Schriften (f.n. 3). Niedersächsisches Staatsarchiv Wolfenbüttel, 1 Alt 22 Nr. 227, Bl. 47-48.

[34] SCHMEH, K.: Versteckte Nachrichten in Modezeichnungen, Grashalmen und Apfelbäumen. In: ScienceBlogs, May 21, 2015 (accessed 06/08/2017), http://scienceblogs.de/klausis-krypto-kolumne/2015/05/21/verstecktenachrichten-in-modezeichnungen-grashalmen-und-apfelbaeumen/

[35] SCHMEH, K.: A musical cryptogram from the 17th century In: ScienceBlogs, Dec. 16, 2016 (accessed 06/08/2017), http://scienceblogs.de/klausis-krypto-kolumne/2016/12/06/a-musical-cryptogram -from-the-17th-century/

The 90-second musical cipher is available on YouTube in two versions: (accessed 06/12/2017), https://youtu.be/XjHtiXE8Iys 


\title{
GERHARD F. STRASSER
}

[36] STRASSER, G.F.: Musik(noten)chiffren oder die 'widernatürliche' Kunst, Musik zu geheimer Kommunikation zu verwenden. In: (Hartmut Laufhütte, ed.) Künste und Natur in Diskursen der Frühen Neuzeit. Wolfenbütteler Arbeiten zur Barockforschung Vol. 34-35, Harrassowitz, Wiesbaden, 2000, pp. 1107-1121.

[37] KIRCHER, A.: Polygraphia Nova et Vniversalis ex Combinatoria Arte detecta [... .]. Varesius, Rome, 1663.

[38] DUKE FERDINAND ALBRECHT I.: (Front matter in his personal copy of) KIRCHER, A.: Polygraphia Nova, Herzog August Bibliothek, Fb $4^{\circ} 78$.

[39] STRASSER, G. F.: Geheimschrift. In: Sammler-Fürst-Gelehrter. Herzog August zu Braunschweig und Lüneburg 1579-1666. Catalogue of the Herzog August Bibliothek Vol. 27. Herzog August Bibliothek, Wolfenbüttel, 1979, pp. 181-191.

[40] SIR DURNING-LAWRENCE, E.: On page 136 of the Shakespeare Folio of 1623, being a portion of the play 'Love's Labour's Lost', and its connection with Gustavi Seleni 'Cryptomenytices'. In: Bacon is Shake-Speare. Gay \& Hancock, London, 1910, pp. 103-133 (especially pp. 112-113).

[41] STRASSER, G.F.: Herzog Augusts Handbuch der Kryptographie: Apologie des Trithemius und wissenschaftliches Sammelwerk. In: Wolfenbütteler Beiträge Vol. 8 (1988), pp. 99-120.

Received June 15, 2017

\author{
Gerhard F. Strasser \\ Professor emeritus \\ Penn State University \\ University Park, PA 16802 \\ U.S.A. \\ E-mail: gfs1@psu.edu
}

